\title{
Chemistry-climate interactions of aerosol nitrate from lightning
}

\author{
Holger Tost \\ Institute for Atmospheric Physics, Johannes Gutenberg University Mainz, Mainz, Germany \\ Correspondence to: Holger Tost (tosth@uni-mainz.de)
}

Received: 18 May 2016 - Published in Atmos. Chem. Phys. Discuss.: 27 June 2016

Revised: 5 January 2017 - Accepted: 6 January 2017 - Published: 24 January 2017

\begin{abstract}
Lightning represents one of the dominant emission sources for $\mathrm{NO}_{x}$ in the troposphere. The direct release of oxidised nitrogen in the upper troposphere does not only affect ozone formation, but also chemical and microphysical properties of aerosol particles in this region. This study investigates the direct impact of $\mathrm{LNO}_{x}$ emissions on uppertropospheric nitrate using a global chemistry climate model. The simulation results show a substantial influence of the lightning emissions on the mixing ratios of nitrate aerosol in the upper troposphere of more than $50 \%$. In addition to the impact on nitrate, lightning substantially affects the oxidising capacity of the atmosphere with substantial implications for gas-phase sulfate formation and new particle formation in the upper troposphere. In conjunction with the condensation of nitrates, substantial differences in the aerosol size distribution occur in the upper troposphere as a consequence of lightning. This has implications for the extinction properties of the aerosol particles and for the cloud optical properties. While the extinction is generally slightly enhanced due to the $\mathrm{LNO}_{x}$ emissions, the response of the clouds is ambiguous due to compensating effects in both liquid and ice clouds. Resulting shortwave flux perturbations are of $\sim-100 \mathrm{~mW} \mathrm{~m}^{-2}$ as determined from several sensitivity scenarios, but an uncertainty range of almost $50 \%$ has to be defined due to the large internal variability of the system and the uncertainties in the multitude of involved processes. Despite the clear statistical significance of the influence of lightning on the nitrate concentrations, the robustness of the findings gradually decreases towards the determination of the radiative flux perturbations.
\end{abstract}

\section{Introduction}

Lightning is one of most energetic phenomena in the Earth's atmosphere. Due to the tremendous electricity, the associated temperatures allow the stable molecular nitrogen compounds to break up into fragments which partly recombine as nitrogen oxides (Schumann and Huntrieser, 2007). Hence lightning represents a natural atmospheric emission source for $\mathrm{NO}_{x}$, in addition to the anthropogenic sources from industry, energy production, traffic and agriculture (e.g. Jaegle et al., 2005). Furthermore, biomass burning contributes significantly to the total $\mathrm{NO}_{x}$ emissions (e.g. van der Werf et al., 2010). The global lightning $\mathrm{NO}_{x}\left(\mathrm{LNO}_{x}\right)$ production has been estimated to range between 2 and $8 \mathrm{Tg} \mathrm{N} \mathrm{yr}^{-1}$ (Schumann and Huntrieser, 2007); hence it is in a similar order of magnitude to the soil emissions (e.g. Steinkamp and Lawrence, 2011), which represent an additional important natural contribution to the total oxidised nitrogen in the atmosphere. In contrast to the other sources (with the exception of aircraft emissions), $\mathrm{LNO}_{x}$ represents an upper-tropospheric source. Due to a different chemical composition and chemical reactivity compared to the boundary layer, chemical conversion into $\mathrm{HNO}_{3}$ is relatively efficient and, most importantly, is not subject to fast removal by dry deposition. Once nitric acid is formed, it can condense onto existing aerosol particles, mostly thermodynamically stabilised by ammonium $\left(\mathrm{NH}_{4}^{+}\right)$, forming ammonium nitrate $\left(\mathrm{NH}_{4} \mathrm{NO}_{3}\right)$. This aerosol species is considered semivolatile such that in the lowermost atmosphere a substantial part of nitrate re-evaporates (e.g. Stelson et al., 1979). However, due to the lower temperatures in the upper troposphere, $\mathrm{NH}_{4} \mathrm{NO}_{3}$ is thermally stabilised, and remains mostly in the aerosol phase. The total amount of nitrate aerosol does not only depend on the available nitric acid, but also on neutralising cations, i.e. mostly ammonium. Furthermore, the con- 
densation rate of nitric-acid-forming nitrates also depends on the available aerosol concentration, as well as competition for neutralising compounds, e.g. with sulfate ions.

Experimental evidence for the occurrence of nitrate in convective outflows have recently been observed over the Amazon by aircraft measurements ${ }^{1}$. Furthermore, $\mathrm{NH}_{3}$ has been observed based on satellite retrievals in the outflow of the Asian monsoon (Höpfner et al., 2016), leading to the conclusion that not all soluble compounds are completely removed by scavenging during convective lifting. Consequently, there is observational evidence for both $\mathrm{NH}_{3}$ and $\mathrm{NO}_{3}^{-}$, such that the formation of $\mathrm{NH}_{4} \mathrm{NO}_{3}$ is likely due to the low temperatures in the upper troposphere. A recent study by Yang et al. (2015) also shows that the observed scavenging efficiencies for nitrate (together with $\mathrm{HNO}_{3}$ ) and ammonium are around $80 \%$ for the DC3 campaign (Barth et al., 2015), which allowed them to conclude that the observed $\mathrm{NO}_{3}^{-}$is most likely formed above the levels of substantial wet removal, e.g. by conversion of lightning $\mathrm{NO}_{x}$.

Being a component of the mixture of aerosol particles, the nitrate aerosol from lightning can also influence atmospheric radiation via the direct and indirect aerosol effects by a multitude of pathways. First, nitrate contributes to water uptake, increasing ambient aerosol size at a given relative humidity. Both the particulate nitrate mass as well as the additional aerosol water enhance the radiative extinction properties of the particle and can even alter the single-scattering albedo, influencing the direct aerosol effect of nitrate particles (e.g. Adams et al., 2001).

Additionally, the overall chemical composition of the aerosol is modified by nitrate from lightning such that the cloud condensation nuclei (CCN) or ice nuclei (IN) efficiency of the particles changes with implications for the indirect aerosol effects. Consequently, this indirect effect should be considered a competition between the formation of additional CCN (e.g. Makkonen et al., 2012) by the nitrate and a potential deactivation of IN for contact or deposition freezing by providing a hygroscopic coating. Immersion freezing is also affected via the concentration of the solutions, IN deactivation and freezing-point modifications.

Currently, only a few global aerosol chemistry climate models can realistically simulate aerosol nitrate and its implications for the direct, and also partially indirect, aerosol effect due to the complex chemical interactions and the semivolatility (e.g. Jacobson, 2001; Adams et al., 2001; Bauer et al., 2007; Bellouin et al., 2011; Xu and Penner, 2012; Makkonen et al., 2012). However, regional-scale air quality models often consider the formation of nitrate and implications of the emissions from various sources on the $\mathrm{NO}_{3}^{-}$ formation, e.g. Zare et al. (2014), who investigate the role of $\mathrm{LNO}_{x}$ on $\mathrm{PM}_{2.5}$ in Europe or Allen et al. (2012), who among other aspects analysed the influence of lightning on nitrate wet deposition in the USA. The effect of $\mathrm{LNO}_{x}$ on

${ }^{1}$ J. Schneider, personal communication, 2016 gas-phase chemistry and the oxidation capacity of the atmosphere have been previously studied and are continuously revisited (e.g. Labrador et al., 2004; Schumann and Huntrieser, 2007; Gressent et al., 2016; Finney et al., 2016a, b).

Usually, the effect of nitrates is determined by annihilation studies; i.e. the effect of nitrates is completely ignored. However, this might have implications for the overall aerosol chemical composition and size distribution such that these effects are mixed with the pure impacts of nitrate. Instead of a total nitrate annihilation scenario, this study investigates the omission of only a fraction of the aerosol nitrate, which originates from the lightning $\mathrm{NO}_{x}$ emissions. According to our knowledge, the resulting climate impacts from lightning caused by particulate nitrate have not yet been quantified with a comprehensive chemistry climate model. Nevertheless, this scenario already reveals strong impacts due to the substantial implications of $\mathrm{LNO}_{x}$ emission on tropospheric chemistry. However, emission sensitivity studies on $\mathrm{LNO}_{x}$ would suffer from an even worse signal-to-noise ratio than that found in the current study.

The results from this study are in agreement with previous studies mentioned above with respect to the impact on ozone and the oxidation capacity, but explicitly analyse the impact of $\mathrm{LNO}_{x}$ on upper-tropospheric nitrate concentrations and its implications for the climate system.

\section{Model description}

\subsection{The EMAC modelling system}

This study applies the ECHAM5/MESSy Atmospheric Chemistry (EMAC) model, which is a numerical chemistry and climate simulation system that includes submodels describing tropospheric and middle atmosphere processes and their interaction with oceans, land and human influences (Jöckel et al., 2010). It uses the second version of the Modular Earth Submodel System (MESSy2) (Jöckel et al., 2005) to link multi-institutional computer codes. The core atmospheric model is the 5th generation European Centre Hamburg general circulation model (ECHAM5, Roeckner et al., 2006). For the present study I applied EMAC (ECHAM5 version 5.3.02, MESSy version 2.50) in the T42L31-resolution, i.e. with a spherical truncation of T42 (corresponding to a quadratic Gaussian grid of approx. 2.8 by $2.8^{\circ}$ in latitude and longitude) with 31 vertical hybrid pressure levels up to $10 \mathrm{hPa}$. The applied model set-up comprised the submodels for radiation, convection, large-scale clouds and condensation and the budget (source, transport and loss processes) of chemical compounds in the gas and aerosol phase.

\subsection{Aerosol climate processes within EMAC}

To simulate the relevant processes mentioned above and sketched in Fig. 1, I employed the lightning $\mathrm{NO}_{x}$ emissions scheme by Price and Rind (1992). This scheme uses convec- 


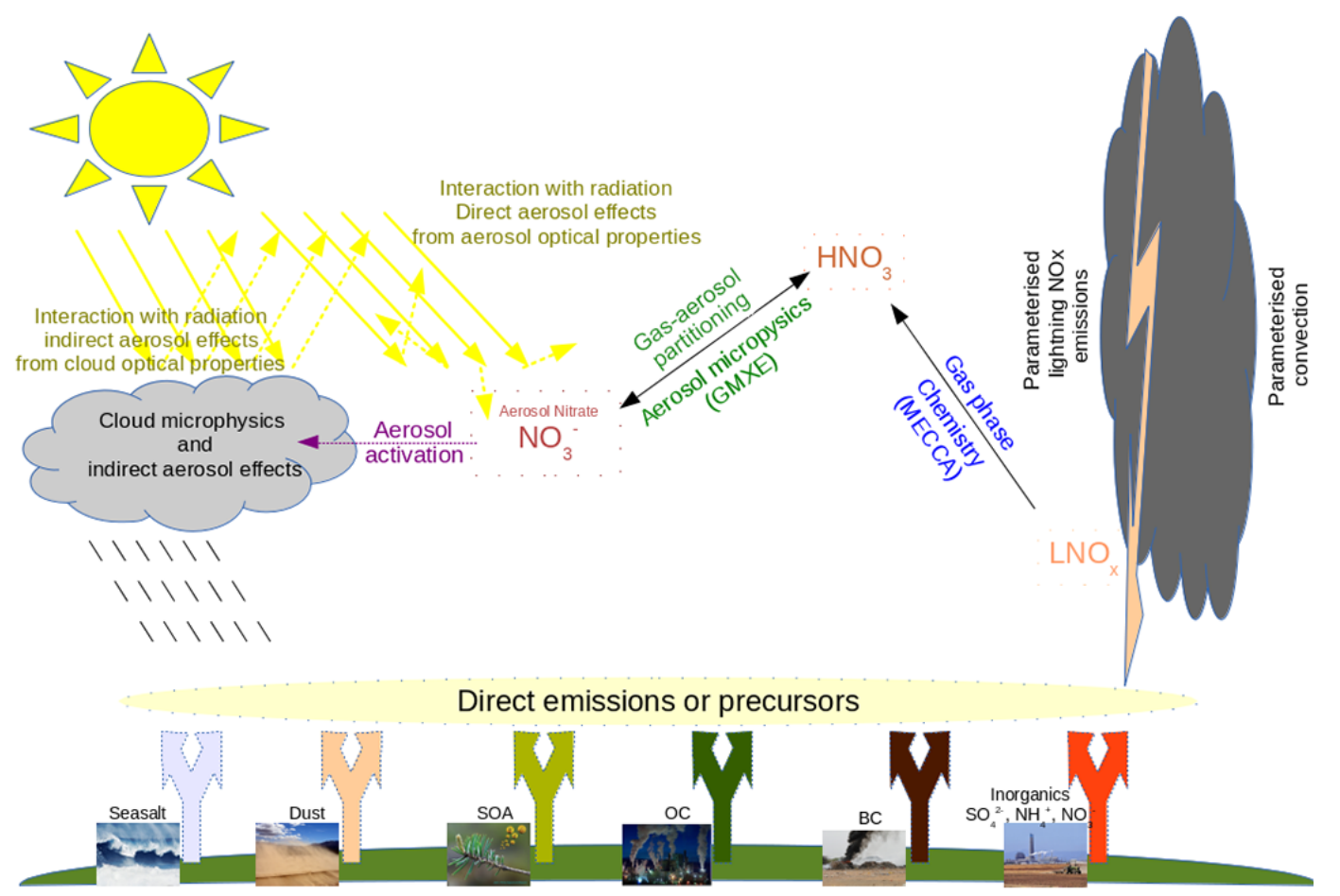

Figure 1. Sketch of the simulated processes from the emission of $\mathrm{NO}_{x}$ molecules by lightning over gas-phase conversion to $\mathrm{HNO}_{3}$, gas aerosol partitioning to particulate $\mathrm{NO}_{3}^{-}$and implications for the direct and indirect aerosol effects.

tive cloud top height as simulated by the convection scheme (Tiedtke, 1989). Even though such a combination of two parameterisations is subject to large uncertainties, we have shown in the past that this special combination is relatively robust and able to provide relatively realistic lightning distributions compared to satellite data from the LIS/OTD sensors (Tost et al., 2007). The emitted NO is subject to gas phase chemical transformations which are calculated with the help of the chemical model MECCA (Sander et al., 2011). The resulting nitric acid $\left(\mathrm{HNO}_{3}\right)$ can subsequently partition into the aerosol phase. The corresponding aerosol processes are simulated with the GMXE aerosol submodel (Pringle et al., 2010; Tost and Pringle, 2012), taking both the gas-aerosolphase partitioning and the interactions with other chemical compounds as well as the microphysical properties of the aerosol particles into account. The gas-aerosol-phase partitioning of inorganic semivolatile compounds is calculated by the ISORROPIA2 model (Fountoukis and Nenes, 2007), which is part of the GMXE aerosol scheme. The aerosol particles are discretised in 4 log-normal size categories, and for the larger three modes a distinction is made between internally mixed hydrophilic particles and externally mixed hydrophobic particles resulting in 7 log-normal modes overall. Additional anthropogenic and natural emissions except for lightning are simulated with the submodels ONEMIS, OFFEMIS and TNUDGE (Kerkweg et al., 2006b), providing sources for other primary and secondary aerosol particles.
Physical loss processes (dry and wet deposition, additionally sedimentation for aerosol processes) are explicitly considered in the schemes DRYDEP, SCAV and SEDI (Kerkweg et al., 2006a; Tost et al., 2006).

To consider aerosol radiation interactions, the prognostic aerosol mass and number concentrations (including aerosol water) are used in look-up tables from Mie calculations precalculated with the LIBRADTRAN (Mayer and Kylling, 2005) to determine the radiative properties of the atmospheric aerosol (extinction, single-scattering albedo, asymmetry parameter) as described in detail in Pozzer et al. (2012), de Meij et al. (2012) and Dietmüller et al. (2016). These parameters are explicitly considered in the radiation scheme native to ECHAM5 (Roeckner et al., 2003), replacing the aerosol climatology by Tanre et al. (1984) as described in Dietmüller et al. (2016). For the treatment of indirect aerosol effects, I have implemented a two-moment cloud microphysics scheme (Lohmann and Hoose, 2009; Lohmann et al., 2010). The activation of aerosols is calculated with the scheme of Abdul-Razzak and Ghan (2000), which has been adapted to the simulated aerosol types. Furthermore, the interactions of aerosols in the homogeneous and heterogeneous freezing processes (Kärcher et al., 2006) are considered, including an adaption to the more comprehensive chemical composition of the aerosol simulated with GMXE. To investigate the sensitivity of the climate impacts of aerosol particles influenced by lightning caused by aerosol-cloud interac- 
tions (ACI), a second set of simulations has been performed using a modified activation scheme based on a combination of the work of Abdul-Razzak and Ghan (2000) and Petters and Kreidenweis (2007), as described in detail by Chang et al. (2014). The set of simulations using the Abdul-Razzak and Ghan (2000) aerosol activation scheme will afterwards be abbreviated ARG; for the other set of simulations following Chang et al. (2014) the acronym KK (Kappa-Koehler) will be used.

Both schemes include the effects of nitrate, but different approaches are followed to calculate the critical supersaturation: the ARG scheme uses parameters for the osmotic coefficient and dissociation of nitrate in the solution (which are more uncertain than for $\left.\left(\mathrm{NH}_{4}\right)_{2} \mathrm{SO}_{4}\right)$, whereas the $\mathrm{KK}$ approach uses a volume weighted $\kappa$ to determine the total aerosol water uptake and hence cloud formation potential. The two approaches are therefore merely a different representation of the Raoult effect in the cloud activation. Note that the aerosol-cloud interactions are only taken into account for large-scale clouds as the treatment of cloud microphysics in convective clouds is even further simplified.

\subsection{Simulation set-up}

Decadal simulations including all feedback mechanisms with the EMAC model have been performed for present-day and preindustrial conditions. Sea surface temperatures are prescribed by a climatology from the AMIPII database for all model configurations. To determine the effects of aerosols caused by lightning, two simulations are performed for each scenario, one with and one without $\mathrm{LNO}_{x}$ emissions. Even though this annihilation scenario potentially cannot capture some compensation effects, I choose this approach due to the expected lower signal-to-noise ratio. Furthermore, as there is nitrate produced from anthropogenic, biomass burning and soil sources of $\mathrm{NO}_{x}$, there is no complete annihilation of all nitrate. For the present-day scenario we applied emissions from the ACCMIP emission inventory (Lamarque et al., 2010, 2013) for trace gases and aerosol emissions from the AEROCOM (Dentener et al., 2006) experiment. For preindustrial conditions I followed the AEROCOM (Dentener et al., 2006) recommendation for preindustrial conditions. Biomass burning is included using the GFED data (van der Werf et al., 2010), as well as a compilation for preindustrial biomass burning. Note that prescribed aerosol emissions for dust and sea salt have been applied, not including a potential feedback of a changed circulation (wind speed and wind patterns) on aerosol sources. The feedback mechanisms are allowed to create an individual climate state without nudging the simulation results towards reanalysis data. The model simulations have been initialised with results from previous experiments (see Jöckel et al., 2016), eliminating spin-up effects and allowing a well-initialised atmospheric composition state including for long-lived compounds such as $\mathrm{CH}_{4}$. Due to the comprehensive feedback mechanisms we refrain from comparing individual years of the simulations, but focus on the decadal mean values and distributions.

\section{Results}

\subsection{Lightning and associated emissions}

To estimate the effects of lightning and associated emissions, I analysed the distribution of $\mathrm{NO}_{x}$ emissions from lightning. Figure 2 depicts the temporal mean emitted $\mathrm{LNO}_{x}$ for the present-day scenario in a 3-D visualisation.

The magnitude of the $\mathrm{LNO}_{x}$ emissions is displayed as an isosurface of $1 \times 10^{-16} \mathrm{~kg} /\left(\mathrm{m}^{3} \mathrm{~s}\right)$. A second isosurface of $3 \times 10^{-16} \mathrm{~kg} /\left(\mathrm{m}^{3} \mathrm{~s}\right)$, which is visible as a darker shading embedded in the first isosurface, shows that the dominant emissions take place in the upper part of the $\mathrm{LNO}_{x}$ plume. This is a consequence of the fact that the vertical emission redistribution follows a C-shaped profile according to Pickering et al. (1998), leading to enhanced emissions in the upper section of the plume. Even though more recent studies (e.g. Ott et al., 2010) suggest a different vertical emission distribution, past studies with the EMAC model have shown good agreement with observations of several campaigns using the C-shaped profiles (Huntrieser et al., 2007; Tost et al., 2010).

The outer emission isosurface is colour coded with the total aerosol nitrate mixing ratio (in mol mol${ }^{-1}$ ), depicting the amount of aerosol nitrate present in the emission peaks. Furthermore, the grey-shaded isosurface visualises a level of $0.1 \mathrm{ppb}_{\mathrm{v}}$ of aerosol nitrate. This shows that high aerosol nitrate concentrations are located in the lower troposphere, but enhanced mixing ratios ( $>100 \mathrm{ppt}_{\mathrm{v}}$ ) of particulate nitrate can also be found in the upper troposphere, partially concurring with the $\mathrm{LNO}_{X}$ emissions (compare the values of up to $100 \mathrm{ppt}_{\mathrm{v}}$ as marked by the colour coding on the emission plume surfaces).

The enhanced $\mathrm{NO}_{3}^{-}$mixing ratios in the lower troposphere can be explained by the anthropogenic $\mathrm{NO}_{x}$ emissions as well as sources for neutralising cations such as $\mathrm{NH}_{4}^{+}$close to the surface.

The coloured map at the bottom of Fig. 2 depicts the mean flash frequency per $\mathrm{km}^{2}$ and minute, which is relatively well confined to the tropical continents and in reasonable agreement with observations from LIS/OTD (updated data following Christian et al. (2003)). Consequently, the $\mathrm{LNO}_{x}$ emissions are co-located over the same regions.

The total $\mathrm{LNO}_{x}$ emissions are $5.95 \mathrm{Tg} \mathrm{N} \mathrm{yr}^{-1}$ with a $1 \sigma$ variability of $0.03 \mathrm{Tg} \mathrm{Nyr}^{-1}$ over the simulated decade in the present-day scenario (ARG). For the KK scenario a total emission strength from lightning with $6.04 \pm 0.03 \mathrm{Tg} \mathrm{N} \mathrm{yr}^{-1}$ is simulated. Note that the seasonal variability is substantially larger. More than $80 \%$ of the emitted $\mathrm{LNO}_{x}$ is placed above $500 \mathrm{hPa}$ altitude in both scenarios. The difference between the two scenarios is a consequence of slightly different 


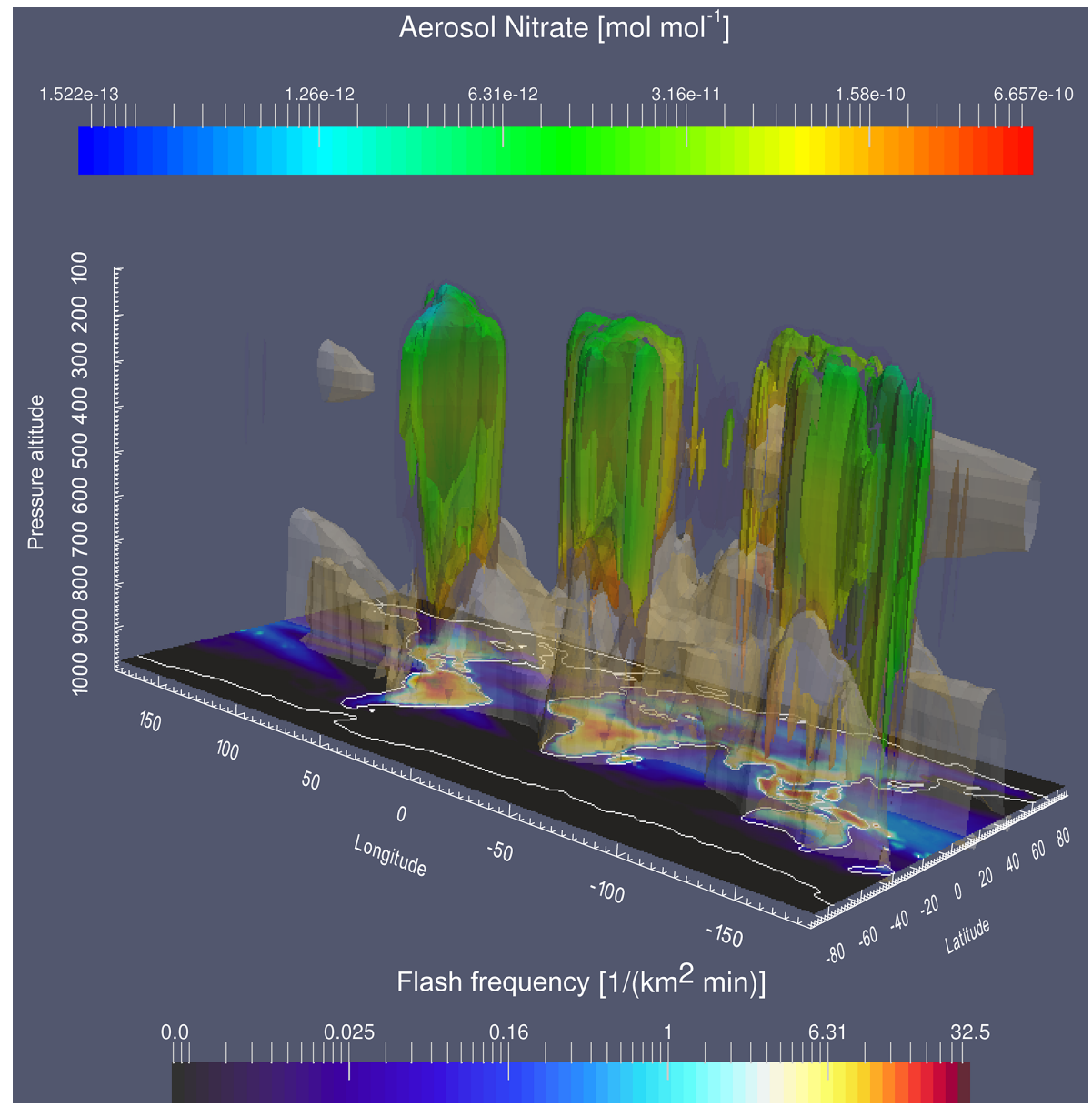

Figure 2. 3-D visualisation of $\mathrm{LNO}_{x}$ emissions (coloured isosurface of $1 \times 10^{-16} \mathrm{~kg} /\left(\mathrm{m}^{3} \mathrm{~s}\right.$ ) and darker-shaded isosurface of $3 \times 10^{-16} \mathrm{~kg} /\left(\mathrm{m}^{3} \mathrm{~s}\right)$ ) and the total aerosol nitrate mixing ratios (grey isosurface of $\left.0.1 \mathrm{ppb}_{\mathrm{v}}\right)$. Additionally, the mean flash rate in $1 /\left(\mathrm{km}^{2}\right.$ min) is depicted by the 2-D slice at the bottom. Note the logarithmic scaling of both colour bars.

meteorological conditions which are caused by the feedback effects of the aerosol and cloud properties.

\subsection{Tropospheric nitrate from lightning}

\subsubsection{Chemical budgets and distribution of oxidised nitrogen compounds}

The emitted $\mathrm{NO}_{x}$ from lightning along with other $\mathrm{NO}_{x}$ molecules in the atmosphere forms $\mathrm{HNO}_{3}$ mostly via the gasphase reaction of $\mathrm{NO}_{2}+\mathrm{OH} \rightarrow \mathrm{HNO}_{3}$ on typical timescales of hours to days. Even though this reaction is much slower than the conversion between $\mathrm{NO}$ and $\mathrm{NO}_{2}$, it represents an important end to the circular conversion of the $\mathrm{NO}_{x}$ species.

The $\mathrm{LNO}_{x}$ emissions for the present-day scenario result in $\sim 40 \%$ higher nitric acid mixing ratios in the troposphere, and even up to $\sim 61 \%$ between $500 \mathrm{hPa}$ and the tropopause, compared to simulations without lightning $\mathrm{NO}_{x}$ emissions (see Table 1). Even though the enhancement effect for $\mathrm{N}_{2} \mathrm{O}_{5}$ is stronger in relative numbers, the overall mixing ratios for
$\mathrm{N}_{2} \mathrm{O}_{5}$ are substantially smaller (almost two orders of magnitude) such that dinitrogen pentoxide plays a minor role for the highly oxidised nitrogen compounds in the troposphere. Peroxyacetyl nitrate (PAN) is found to see a reduction of $15 \%$ for the whole troposphere and $21 \%$ in the upper troposphere when no lightning emissions are considered; therefore it is less affected by the $\mathrm{LNO}_{x}$ emissions due to a potential limitation of VOCs for PAN formation.

The nitric acid molecules can condense on pre-existing aerosol particles forming $\mathrm{NO}_{3}^{-}$ions in the deliquesced aerosol solution or solid $\mathrm{NH}_{4} \mathrm{NO}_{3}$ or $\mathrm{NaNO}_{3}$ crystals. Tropospheric nitrate mixing ratios are typically a factor of 2 to 3 lower compared to $\mathrm{HNO}_{3}$. Nevertheless, the globally averaged changes in upper-tropospheric $\mathrm{NO}_{3}^{-}$mixing ratios are $\sim 32 \%$.

Figure 3 shows isosurfaces of tropospheric nitrate concentration differences between the simulation with $\mathrm{LNO}_{x}$ emissions and the case without this source. The grey-shaded isosurface depicts a $30 \%$ difference, the blue isosurface $45 \%$ differences and the red enclosed area $60 \%$ enhanced $\mathrm{NO}_{3}^{-}$ 


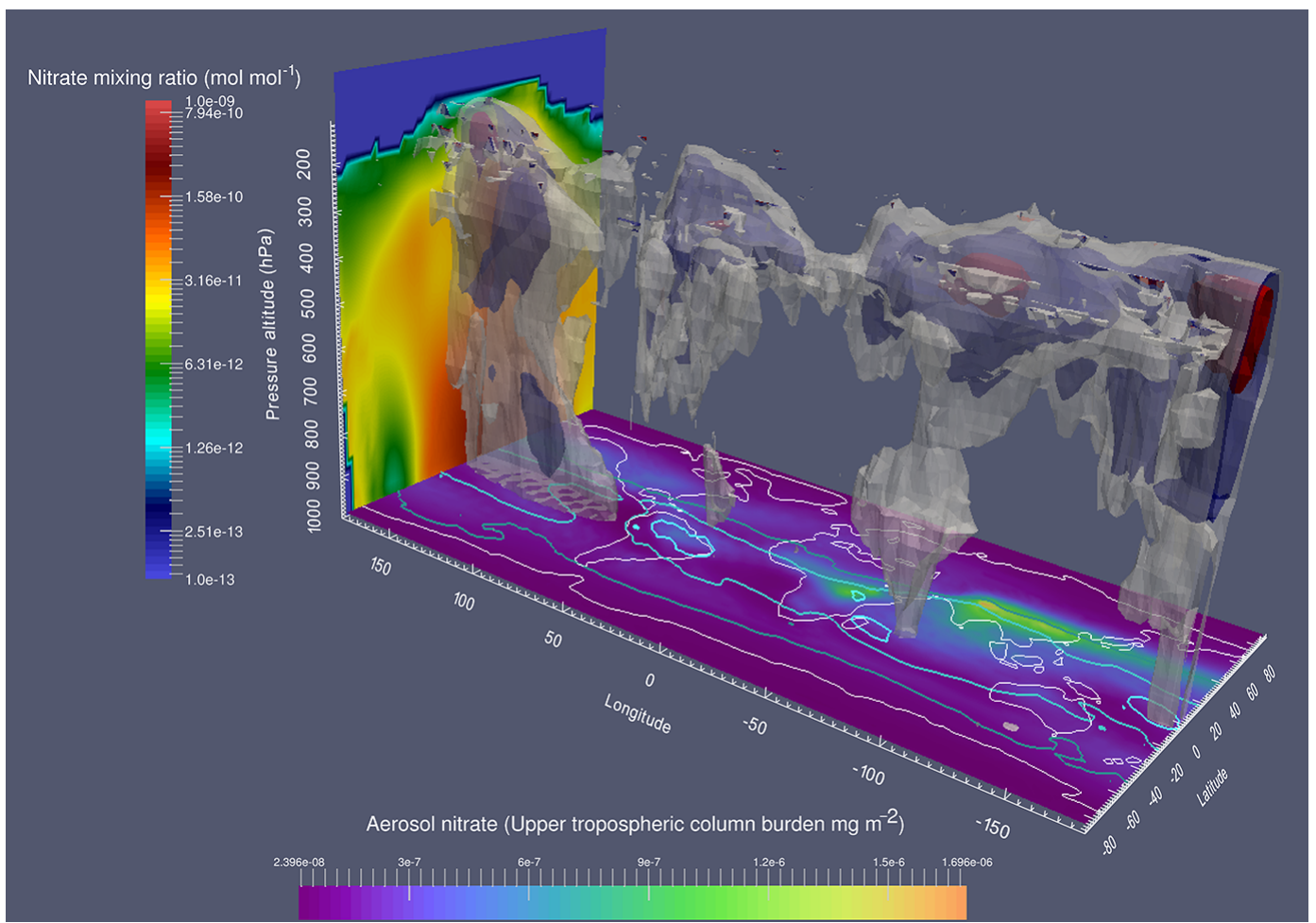

Figure 3. 3-D visualisation of the relative differences in tropospheric aerosol nitrate mixing ratios between the simulations with and without $\mathrm{LNO}_{x}$ emissions to the simulation including $\mathrm{LNO}_{x}$ emissions. The grey isosurface depicts a relative difference of $30 \%$, the blue isosurface of $45 \%$, and the red isosurface of $60 \%$. Additionally, the upper-tropospheric aerosol nitrate column burden (in $\mathrm{mg} \mathrm{m}^{-2}$ ) between $500 \mathrm{hPa}$ and the tropopause is depicted by the coloured panel at the bottom of the graph. The turquoise contour lines depict relative differences of 20 , 40 and $60 \%$ difference in this column burden between the two simulations.

mixing ratios, with only statistically significant data shown (based on a two-sided t-test of annual mean data with a significance level of $90 \%$ ). Even though the maximum $\mathrm{NO}_{3}^{-}$ absolute differences occur down to the surface, the largest relative differences are apparent in the UT. Most of these differences are constrained to the tropics where the strongest $\mathrm{LNO}_{x}$ emissions are prevalent. However, the maxima in the differences are not directly co-located with the emission maxima (i.e. central Africa, Amazonia and the maritime continent; see Fig. 2), but generally further downwind. This is a consequence of atmospheric transport during the time required for oxidation of $\mathrm{NO}_{x}$ to $\mathrm{HNO}_{3}$ and subsequent partitioning into the aerosol phase.

To provide an estimate of the total amount of nitrate in the upper troposphere, the back panel of Fig. 3 depicts the zonal mean $\mathrm{NO}_{3}^{-}$mixing ratio with values between 10 and $100 \mathrm{ppt}_{\mathrm{v}}$ for the tropical middle and upper troposphere where the impact of the $\mathrm{LNO}_{x}$ emissions is largest.

The mean upper-tropospheric column burden $(500 \mathrm{hPa}$ to the tropopause) in $\mathrm{mg} \mathrm{m}^{-2}$ is depicted by the coloured panel at the bottom of the plot. The turquoise isolines on this panel depict the 20, 40 and $60 \%$ differences in the UT column burden between the simulations with and without $\mathrm{LNO}_{x}$ emis- sions. These are of course co-located with the regions of the isosurfaces.

The figure shows that the tropical upper troposphere is a region in which substantial amounts of particulate nitrate can be found. Both visualisations of the differences (UT column burden and mixing ratios) show that a large contribution of the upper-tropospheric $\mathrm{NO}_{3}^{-}$originates from lightning emissions, but also that a sufficient number of neutralising cations are available to stabilise the nitrate in the particulate phase. These findings are a direct consequence of the emission and conversion of $\mathrm{NO}_{x}$ to $\mathrm{N}(\mathrm{V})$, but of course are also indirectly affected by changes in the oxidation capacity of the atmosphere and hence in the $\mathrm{HNO}_{3}$ formation.

The tropospheric budget of the highly oxidised $\mathrm{N}$ compounds is summarised in Table 1, including the relative importance of the $\mathrm{LNO}_{x}$ emissions.

For present-day conditions, the particulate nitrate contribution to the total $\mathrm{N}(\mathrm{V})$ is $\sim 25 \%$, whereas in the upper troposphere it is only $\sim 13 \%$. These numbers have been determined from Table 1 by the contribution calculation of the individual compounds from the total load.

The neglect of the $\mathrm{LNO}_{x}$ emissions leads to a shift in the contribution of the particulate phase to the total $\mathrm{N}(\mathrm{V})$. Under these conditions, $33 \%$ of the $\mathrm{N}(\mathrm{V})$ is in the form of partic- 
Table 1. Tropospheric and upper-tropospheric burden in the ARG simulation of the important highly oxidised nitrogen species, i.e. gaseous $\mathrm{HNO}_{3}$, gaseous $\mathrm{N}_{2} \mathrm{O}_{5}$, aerosol $\mathrm{NO}_{3}^{-}$and the sum of those three compounds. All values are given in $\mathrm{Gg} \mathrm{N}$ (except for the relative differences which are provided in \%) and are globally and vertically integrated over the whole of the upper troposphere (500 hPa up to the tropopause).

\begin{tabular}{|c|c|c|c|c|}
\hline & $\mathrm{HNO}_{3}$ & $\mathrm{~N}_{2} \mathrm{O}_{5}$ & $\mathrm{NO}_{3}^{-}$ & $\begin{array}{r}\text { Total N } \\
(\mathrm{V}+)\end{array}$ \\
\hline \multicolumn{5}{|l|}{ Present day } \\
\hline \multicolumn{5}{|c|}{ Absolute values (with $\mathrm{LNO}_{x}$ emissions): } \\
\hline Tropospheric column burden & 403 & 8.0 & 143 & 554 \\
\hline UT column burden & 174 & 5.0 & 27.8 & 207 \\
\hline \multicolumn{5}{|c|}{ Absolute differences due to $\mathrm{LNO}_{x}$ emissions: } \\
\hline Tropospheric column burden & 162 & 3.9 & 20.0 & 186 \\
\hline UT column burden & 107 & 3.5 & 9.0 & 119 \\
\hline \multicolumn{5}{|c|}{ Relative differences in $(\%)$ due to $\mathrm{LNO}_{x}$ emissions: } \\
\hline Tropospheric column burden & 40.1 & 48.4 & 14.0 & 33.5 \\
\hline UT column burden & 61.3 & 70.3 & 32.3 & 57.7 \\
\hline \multicolumn{5}{|l|}{ Preindustrial conditions } \\
\hline \multicolumn{5}{|c|}{ Absolute values (with $\mathrm{LNO}_{x}$ emissions): } \\
\hline Tropospheric column burden & 238 & 4.5 & 67.8 & 310 \\
\hline UT column burden & 143 & 4.1 & 15.0 & 161 \\
\hline \multicolumn{5}{|c|}{ Absolute differences due to $\mathrm{LNO}_{x}$ emissions: } \\
\hline Tropospheric column burden & 158 & 3.7 & 25.8 & 188 \\
\hline UT column burden & 110 & 3.5 & 8.1 & 121 \\
\hline \multicolumn{5}{|c|}{ Relative differences in (\%) due to $\mathrm{LNO}_{x}$ emissions: } \\
\hline Tropospheric column burden & 66.6 & 82.6 & 38.1 & 60.6 \\
\hline UT column burden & 76.9 & 86.0 & 54.3 & 75.1 \\
\hline
\end{tabular}

ulate $\mathrm{NO}_{3}^{-}$for the whole troposphere, whereas for the UT the fraction is higher than $21 \%$. This is a consequence of the reduced amount of available $\mathrm{N}(\mathrm{V})$, but a similar number of neutralising cations, i.e. mostly $\mathrm{NH}_{4}^{+}$.

The sensitivity simulations in the KK configuration result in almost identical values (budget is shown in Table S1 of the Supplement), depicting the fact that the description of cloud and cloud removal processes plays a minor role in the total budget of particulate nitrate in both model configurations.

The budget of the loss processes of $\mathrm{N}(\mathrm{V})$ compounds can be found in the Supplement for both present-day and preindustrial conditions. The differences in the nitrate burden are similarly present in the loss processes, with wet deposition being mostly influenced (50\% change in the loss flux), but sedimentation and dry deposition also equally contributing to the change in the total loss.

\subsubsection{Influences on other chemical species}

The reduced $\mathrm{NO}_{x}$ burden in the simulation without lightning emissions has substantial impact on the concentrations of other species. As only a minor fraction of the total $\mathrm{LNO}_{X}$ emissions of $\sim 6 \mathrm{Tg} \mathrm{Nyr}^{-1}$ are converted to $\mathrm{N}(\mathrm{V}+)$ (e.g. $186 \mathrm{Gg} \mathrm{N}$ change in $\mathrm{N}(\mathrm{V})$ according to Table 1), the impact on ozone is comparable to previous studies (e.g.
Table 2. $\mathrm{CH}_{4}$ tropospheric and upper-tropospheric $(500 \mathrm{hPa}$ to tropopause) lifetime and absolute change due to $\mathrm{LNO}_{x}$ emissions.

\begin{tabular}{|c|c|c|}
\hline & $\begin{array}{r}\mathrm{CH}_{4} \text { lifetime } \\
\text { [years] }\end{array}$ & $\begin{array}{r}\text { Increase of the } \mathrm{CH}_{4} \\
\text { lifetime [years] }\end{array}$ \\
\hline \multicolumn{3}{|l|}{ Present day } \\
\hline Troposphere & 7.4 & 1.7 \\
\hline UT only & 14.0 & 9.7 \\
\hline \multicolumn{3}{|c|}{ Preindustrial conditions } \\
\hline Troposphere & 8.9 & 1.9 \\
\hline UT only & 14.1 & 13.2 \\
\hline \multicolumn{3}{|c|}{$\begin{array}{l}\text { The } \mathrm{CH}_{4} \text { lifetime is calculated with the help of the actual methane and } \\
\mathrm{OH} \text { concentrations, calculating a pseudo-first-order loss rate. The } \\
\text { corresponding temperature-dependent reaction rate is identical to the } \\
\text { one used in the online chemistry calculations, also using the } \\
\text { temperature output of the simulations. Calculating the lifetime for each } \\
\text { individual cell, average values are determined using grid } \\
\text { mass-weighted factors for certain regions or the whole troposphere. }\end{array}$} \\
\hline
\end{tabular}

Labrador et al., 2005; Finney et al., 2016a): the calculated values for tropospheric ozone are $362 \mathrm{Tg}$ in the simulation without lightning and $444 \mathrm{Tg}$ if lightning is included, which corresponds to a $22 \%$ increase in the tropospheric ozone burden (even though the absolute values for the tropospheric ozone burden differ substantially in each of the studies). The effect of the $\mathrm{LNO}_{x}$ emissions is again very prominent in the upper troposphere, where the $\mathrm{O}_{3}$ load increases from 195 to $248 \mathrm{Tg}$ by $\mathrm{LNO}_{x}$ emissions, i.e. an increase of $27 \%$. Driven by the location of most of the emissions, these effects mostly occur in the low latitudes. The decrease in ozone in the zonal average resulting from neglecting lightning emissions is comparable to the findings of Grewe (2007). The change in the column burdens in the tropics also agrees with the results of Martin et al. (2002), both in the geographic patterns and the amplitude of the signal. Therefore, the explicit consideration of the nitrate formation has no important impact on the tropospheric ozone distribution, such that the results of impact studies of lightning $\mathrm{NO}_{x}$ (such as e.g. Banerjee et al., 2014) do not have to be revised.

However, the $\mathrm{OH}$ concentrations, and therefore the oxidation capacity of the atmosphere, are also substantially influenced by lightning (Labrador et al., 2004) via changes in $\mathrm{O}_{3}$ and subsequent $\mathrm{OH}$ production via ozone photolysis and reaction of the products with water vapour. The effect on $\mathrm{OH}$ is displayed by modifying the methane lifetime to additionally take the $\mathrm{OH}$ recycling capacity into account, as depicted in Table 2. The emissions of $\mathrm{LNO}_{x}$ are responsible for an increase of the tropospheric methane lifetime from $\sim 1.7$ to 1.9 years; however in the upper troposphere (above $500 \mathrm{hPa}$ up to the tropopause) the $\mathrm{CH}_{4}$ lifetime of almost 10 and 13.2 years for present and preindustrial conditions increases, corresponding to almost a halving of the oxidation capacity of the upper troposphere. The direct $\mathrm{OH}$ concentrations differ only by $\sim 10$ to $20 \%$, showing the importance of the 
recycling mechanisms on the oxidation capacity of the atmosphere.

This is especially relevant for the production of sulfate via the gas-phase oxidation of $\mathrm{SO}_{2}$, which substantially influences aerosol formation and aerosol composition in the upper troposphere. The sulfate burden for present-day conditions decreases from $576 \mathrm{Gg} \mathrm{S}(\mathrm{VI})$ to $565 \mathrm{Gg}$. This is also prominent in the UT region, where instead of $74.6 \mathrm{Gg} \mathrm{S}(\mathrm{VI})$, only $70.2 \mathrm{Gg} \mathrm{S}(\mathrm{VI})$ are simulated. As most of the oxidation in the upper troposphere takes place in the gas phase, the aqueous-phase oxidation in the lower troposphere is affected to a minor degree. Additionally, most of the emitted $\mathrm{SO}_{2}$ in the lower troposphere originates from anthropogenic sources, where the co-emission of $\mathrm{NO}_{x}$ is also prevalent such that the oxidant levels for aqueous-phase oxidation of S(IV) to $\mathrm{S}(\mathrm{VI})$ are less affected.

Particulate ammonium mixing ratios are only affected to a minor degree by the $\mathrm{LNO}_{x}$ emissions, too: for presentday conditions the $\mathrm{NH}_{4}^{+}$burden slightly decreases without lightning emissions, but increases during preindustrial times. However, the changes in the atmospheric burden are lower than $\pm 5 \%$. These changes can be explained by the lower sulfate and nitrate burdens and effects of the oxidation capacity on gaseous ammonium concentrations. A significant change due to $\mathrm{LNO}_{x}$ emissions in the sulfate to bisulfate ratio is not simulated by the model despite the capabilities of the thermodynamic equilibrium model.

The KK simulations show a very similar behaviour in the burdens, the $\mathrm{CH}_{4}$ lifetime and the changes induced by the omission of the $\mathrm{LNO}_{x}$ emissions, such that a detailed discussion is skipped here.

\subsection{Aerosol microphysical effects}

The influences of the chemical composition in the upper troposphere due to lightning are also reflected in the microphysical properties of the aerosol, which are described by the size distributions at various locations. The regions in the tropics are mostly characteristic of the tropical continents, as the oceanic aerosol distributions usually contain substantially lower particle concentrations such that the distribution of those regions is dominated by the continental grid cells. The regions have been selected following the analysis of the significant changes in Sect. 3.2.1, but also to represent various conditions of typical aerosol size distributions where lightning can play an important or only a minor role.

The temporal mean size distributions of the aerosol particles for various regions (the respective regions are mentioned above the individual panels) are shown in Fig. 4 as a 2-D plot with the horizontal axis depicting the ambient aerosol diameter and the vertical axis the pressure altitude; the colour coding displays the relative difference in aerosol number concentration [in \%] between the simulation with and without lightning (NOLNOX-LNOX/LNOX). Furthermore, the absolute values of the size distribution (in $\mathrm{cm}^{-3}$ in a logarith- mic scale) are depicted by the contour lines with the solid lines representing concentrations larger than 1 per $\mathrm{cm}^{3}$. The figure shows the simulation results for the present-day conditions (ARG case). The hatched regions in the 2-D size distribution diagram mark those areas in which the changes do not exhibit statistical significance.

Over the tropical continents (middle row in Fig. 4) in the upper troposphere, enhanced nucleation-mode particle numbers are simulated if lightning emissions are considered, which is a result of the enhanced S(VI) concentrations and, consequently, the new enhanced particle formation. At approximately $10 \mathrm{~nm}$ diameter the particle number is smaller in the case of $\mathrm{LNO}_{x}$ emissions due to the interaction of enhanced coagulation and condensation on the enhanced particle concentrations. Also additional condensation on existing particles and enhanced coagulation with the small particles causes higher values of particle numbers at $\sim 80 \mathrm{~nm}$ in the LNOX case. For larger particles, slightly enhanced values are found in case $\mathrm{LNO}_{x}$ emissions are considered a consequence of the more efficient coagulation (due to higher particle numbers in the small mode) versus the slower condensational growth. For the lower troposphere the picture is more ambiguous and most changes are not statistically significant: in South America and Indonesia reduced nucleation takes place. However, the absolute particle concentrations are so low that this process is almost negligible, whereas in central Africa enhanced new particle formation is caused by lightning emissions. For the larger particles the impact is rather small.

In the midlatitudes (upper row in Fig. 4) relevant changes in the size distributions are only found in the eastern USA and China but little impact in Europe and Siberia (lower right panel). The first two regions are located slightly more southwards such that lightning frequencies are enhanced compared to the latter two regions (see bottom map of Fig. 2). The general pattern of the changes is comparable to the tropical continents.

In the southern Atlantic region the changes in the size distribution profile are relatively small, as lightning emissions play a minor role in the total particle concentration as well as for the oxidation capacity of the atmosphere and therefore sulfate formation, but they are still robust. In the central Pacific where enhanced nitrate concentrations are simulated in the upper troposphere (see Fig. 3), the changes in the aerosol size distribution are moderate with the strongest signals in the middle troposphere (between 700 and $500 \mathrm{hPa}$ ). As lightning $\mathrm{NO}_{x}$ emissions are substantially smaller over the ocean, the oxidation capacity is affected to a minor degree; however nitrate and gaseous $\mathrm{N}(\mathrm{V})$ are transported downwind from the source region, affecting the nitrate concentrations and particle numbers, mostly via coagulation.

To analyse the impact of the $\mathrm{LNO}_{x}$ emissions on the aerosol water uptake, the mean growth factor $(\mathrm{GF}=$ ambient diameter/dry diameter) is compared. Using this parameter has the advantage that, e.g. in contrast to the aerosol wa- 

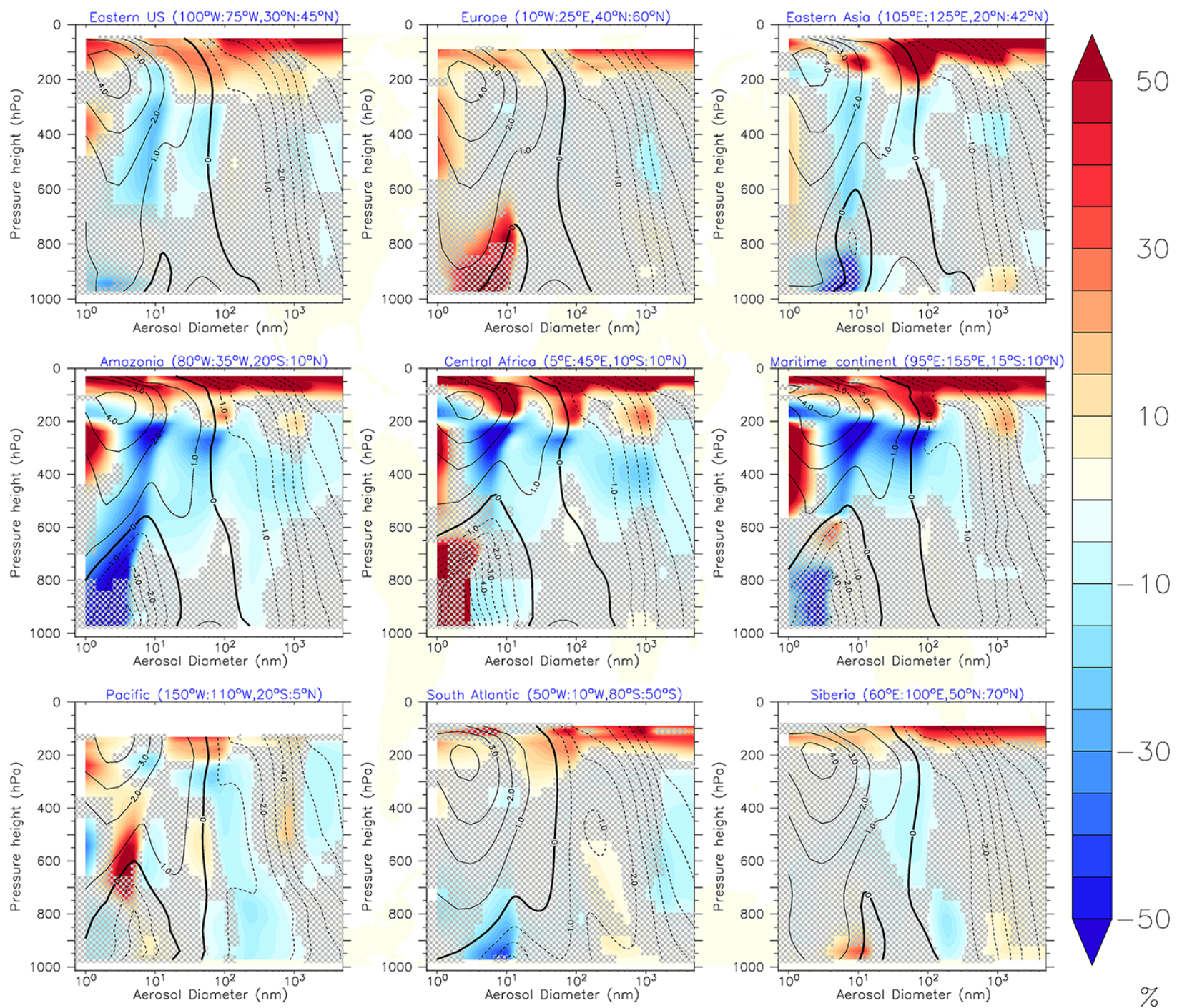

Figure 4. Nine-panel plot of the vertically resolved percentage differences (including $\mathrm{LNO}_{x}$ emissions as the reference case, i.e. (NOLNOX$\mathrm{LNOX} / \mathrm{LNOX}$ ) in the aerosol size distributions as spatial and regional averages (for the respective regions). In each small frame the $y$ axis depicts pressure altitude and the $x$ axis the aerosol diameter from $1 \mathrm{~nm}$ to $10 \mu \mathrm{m}$. Overlayed are the contours of the absolute values of the size distributions, i.e. the absolute particle numbers calculated from overlaying the individual modes determined from the spatial and temporal mean in particles $\mathrm{cm}^{-3}$. The solid lines depict $1,10,100,1000$ particles, whereas the dashed lines represent $10^{-1}$, $10^{-2}$, etc. particles. The figure depicts the present-day conditions. The respective regions are the central Pacific $\left(150^{\circ} \mathrm{W}: 110^{\circ} \mathrm{W}, 20^{\circ} \mathrm{S}: 0\right)$, Amazonia $\left(80^{\circ} \mathrm{W}: 35^{\circ} \mathrm{W}, 20^{\circ} \mathrm{S}: 10^{\circ} \mathrm{N}\right)$, eastern USA $\left(100^{\circ} \mathrm{W}: 75^{\circ} \mathrm{W}, 30^{\circ} \mathrm{N}: 45^{\circ} \mathrm{N}\right)$, South Atlantic $\left(50^{\circ} \mathrm{W}: 10^{\circ} \mathrm{W}, 80^{\circ} \mathrm{S}: 50^{\circ} \mathrm{S}\right)$, central $\mathrm{Africa}$ $\left(5^{\circ} \mathrm{E}: 45^{\circ} \mathrm{E}, 10^{\circ} \mathrm{S}: 10^{\circ} \mathrm{N}\right)$, Europe $\left(10^{\circ} \mathrm{W}: 25^{\circ} \mathrm{E}, 40^{\circ} \mathrm{N}: 60^{\circ} \mathrm{N}\right)$, Indonesia $\left(95^{\circ} \mathrm{E}: 155^{\circ} \mathrm{E}, 12^{\circ} \mathrm{S}: 10^{\circ} \mathrm{N}\right)$, East Asia $\left(105^{\circ} \mathrm{E}: 125^{\circ} \mathrm{E}\right.$, $\left.20^{\circ} \mathrm{N}: 42^{\circ} \mathrm{N}\right)$, Siberia $\left(60^{\circ} \mathrm{E}: 100^{\circ} \mathrm{E}, 50^{\circ} \mathrm{N}: 70^{\circ} \mathrm{N}\right)$. The hatched regions mask areas without statistical significance.

ter content, it is independent of the aerosol size and particle number concentrations. The overall impact of lightning on the GF is relatively small: for present-day conditions the nucleation and Aitken mode depict a slight increase in the upper troposphere (up to $2 \%$ ), whereas in the accumulation and coarse mode a decrease of up to $-2 \%$ is simulated by $\mathrm{LNO}_{x}$ emissions. Due to the relatively dry conditions in the upper troposphere, where the nitrate changes are strongest, the effect on water uptake is expected to be that small. Closer to the surface the differences in the growth factor are even smaller and ambiguous in their signs, lacking statistical significance.

\subsection{Impacts on climate}

\subsubsection{Aerosol optical properties}

As aerosol particles scatter and absorb solar and infrared radiation, the impact of the $\mathrm{LNO}_{x}$ emissions is investigated with the help of Fig. 5 for the ARG present-day simulation. 

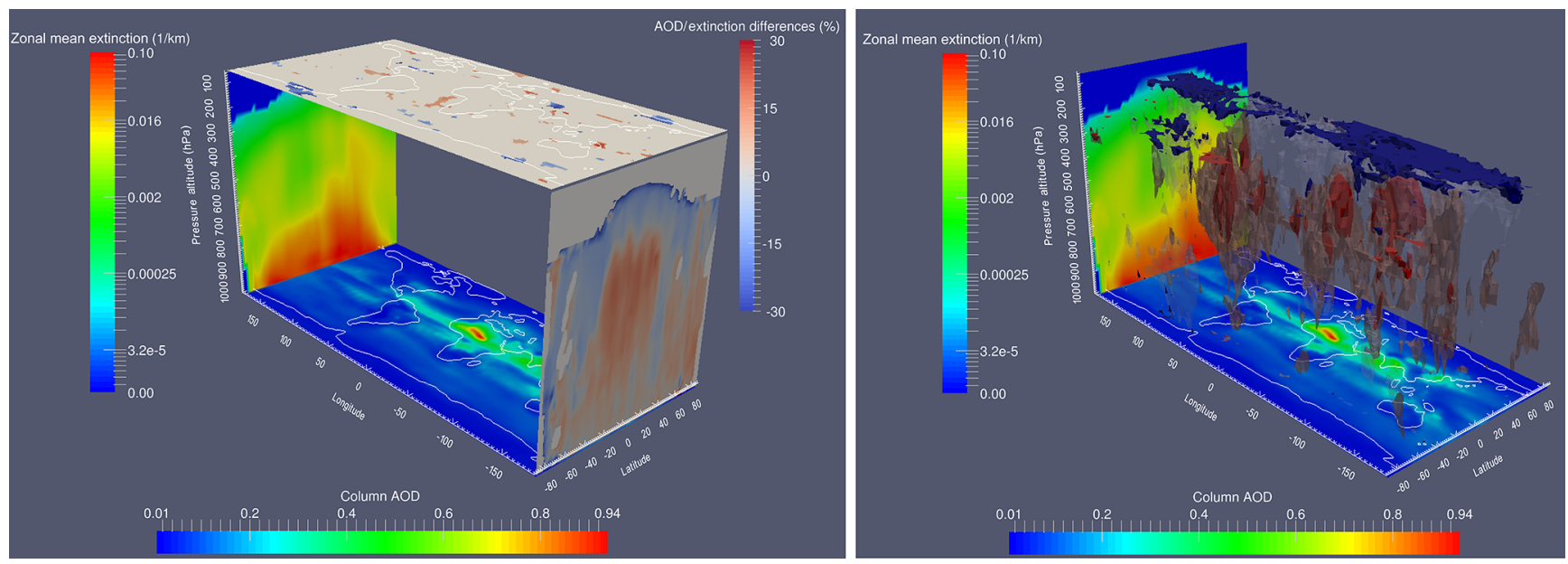

Figure 5. 3-D visualisation of aerosol extinction and the influence of $\mathrm{LNO}_{x}$ emissions. The left panel shows a map of the vertically integrated column AOD (at $550 \mathrm{~nm}$ ) when lightning emissions are included (floor plane). The ceiling depicts the relative differences of the integrated column AOD between the simulation with lightning emissions minus the simulation without lightning $\mathrm{LNO}_{x}$, with the full set-up serving as a reference. The back panel displays the zonal average aerosol extinction (in $1 \mathrm{~km}$ at $550 \mathrm{~nm}$ ) of the full simulations (Please note the logarithmic scale.). The front panel depicts relative percentage differences due to $\mathrm{NO}_{x}$ emissions from lightning. White areas mark regions without statistical significance. The right panel also shows AOD (floor) and zonal mean extinction (rear panel), and additionally 3-D isosurfaces in the centre of the box represent the $+10 \%$ (pale red) and $+20 \%$ (dark red) of the enhanced extinction due to active $\mathrm{LNO}_{x}$ emissions, whereas the $-10 \%$ (pale blue) and $-20 \%$ (dark blue) isosurfaces mark regions in which the emissions result in a reduction of the extinction.

The left panel shows both the mean column AOD at $550 \mathrm{~nm}$ wavelength (on the floor level) as well as the zonal mean extinction (rear panel). The ceiling panel depicts statistically significant changes in the column AOD and the front panel visualises statistically significant changes in the extinction. Note that for determining the zonal mean of statistically significant changes, only the individual data points which exhibit significance are selected and the average over these (selected) points is taken.

The rear panel depicts the zonal mean of the average extinction per kilometre. Substantial extinction is simulated in the lower troposphere (below $700 \mathrm{hPa}$ ) with an additional enhancement of the optical depth between 20 and $50^{\circ} \mathrm{N}$. In the tropical lower troposphere this is a consequence of the distribution of water vapour leading to aerosol water uptake and therefore enhanced growth and extinction. Additionally, the enhanced extinction results from natural sources of dust as well as from anthropogenic pollution (especially from East Asia). The relative changes of aerosol extinction due to $\mathrm{LNO}_{x}$ are depicted in the front panel. The most substantial enhancement of aerosol extinction is simulated in the middle to upper troposphere in the tropics with zonal mean enhancements higher than $20 \%$. In the uppermost troposphere reductions in extinction are also simulated as a consequence of neglecting the lightning emissions. Compared to the nitrate enhancements as analysed from Fig. 3, the maximum enhancement of aerosol extinction by $\mathrm{LNO}_{x}$ is located further down in the middle troposphere, i.e. between 400 and $600 \mathrm{hPa}$, whereas the strongest nitrate enhancement has been simu- lated between 200 and $400 \mathrm{hPa}$. The reason for this downward shift is discussed further below.

The column AOD (floor panel) shows maximum values in the dust emission regions (e.g. northern Africa) and the anthropogenic pollution centres (e.g. eastern China). The climatological global mean value with present-day emissions is 0.122 , which is close to the observations derived from MODIS (e.g. Mao et al., 2014). The influence of the $\mathrm{LNO}_{x}$ emissions can be analysed with the help of the ceiling map in Fig. 5, which shows the percentage fractions of the changes in the simulated AOD. Globally a slight reduction to 0.121 can be found $(\sim 1 \%)$. However, in some regions even higher extinction is simulated in cases of no nitrate formation from lightning, which is in contrast to the findings of Sect. 3.2.1, where no regions with enhanced nitrate have been simulated. However, only in very few regions can a statistically significant signal in the column AOD be found. This is a consequence of the fact that significant changes in extinction are mostly located in the upper troposphere which contributes less to total column AOD (cf. rear panel). The right panel of Fig. 5 again depicts the absolute values of AOD (floor panel) and extinction (rear panel), but also shows isosurfaces of the location of the regions of enhancement and reduction of extinction. The pale red region depicts the $+10 \%$ isosurface, whereas the embedded dark red regions mark an increase of the extinction due to $\mathrm{LNO}_{x}$ of more than $+20 \%$. On the other hand, the pale blue marks regions with medium reduction $(-10 \%)$ and dark blue regions (only at the tropopause) depict extinction reductions of more than $20 \%$. The main enhancement of extinction by lightning emissions occurs 
between 400 and $600 \mathrm{hPa}$ over the tropical continents and slightly further downwind. This general pattern corresponds to the enhanced nitrate mixing ratios (cf. Fig. 3), but is more restricted to the continents. In the extratropics an even higher extinction is simulated if no $\mathrm{LNO}_{x}$ emissions are considered. This is a consequence of the secondary effects caused by the emissions, i.e. the influence on sulfur oxidation via the oxidation capacity of the atmosphere and changes in the size distribution. By comparing the pattern correlation between the changes in nitrate and extinction, a relatively low value is found $(R \approx 0.3)$. However, the changes in sulfate and extinction show a higher correlation value of $R \approx 0.4$. Analysing the probability density function (PDF) of the differences in AOD between the simulation with and without lightning emissions (see Supplement) reveals that for present-day conditions larger deviations occur more often compared to preindustrial cases. The PDFs are almost symmetric, but show a slight shift towards enhanced extinction in the simulations including $\mathrm{LNO}_{x}$ emissions.

The sensitivity simulations with the alternative warm cloud activation scheme in general show a similar distribution of the aerosol extinction with the enhancement in the middle and upper tropical troposphere (see Supplement). The global mean column AOD for present-day conditions is slightly lower (0.120) and the reduction in case of no $\mathrm{LNO}_{x}$ emissions reduced even further $(\sim 0.5 \%)$. The strongest enhancement is found over the tropical continents, i.e. the regions with maximum lightning activity, but most of the nitrate is simulated in the upper troposphere, whereas in this configuration the extinction is also enhanced in the middle to upper troposphere. For preindustrial conditions, the enhancement of the extinction by lightning is a bit stronger, but still small ( 1\%).

To analyse whether the contribution of scattering versus absorption is influenced by the $\mathrm{LNO}_{x}$ emissions, the singlescattering albedo is compared in both model simulations. The zonal mean value changes by less than $\sim+1 \%$ in the free troposphere and stratosphere, and is reduced by a maximum of $\sim-4 \%$ in the boundary layer when lightning emissions are considered. Consequently, a change in the thermodynamic structure resulting from direct aerosol-radiation interactions is expected to be small.

\subsubsection{Cloud properties}

As cloud properties can be influenced indirectly by the $\mathrm{LNO}_{x}$ emissions, three parameters are analysed to provide the causes for aerosol-cloud-radiation interactions. The cloud cover may hint at modifications of the cloud lifetime effect (Albrecht, 1989), whereas the combination of the liquid (ice) water content and the cloud droplet (ice crystal) numbers, which can also be expressed via the effective radii, can shed light onto the direct influence of the lightning emissions on the radiative properties of the clouds via the Twomey (1977) effect.
- Cloud cover: the cloud and precipitation cover changes only to a minor degree between the simulations with and without lightning for the present-day scenario (ARG case). In the tropics, the $\mathrm{LNO}_{x}$ emissions lead to a small increase in the mid-troposphere cloud coverage of the Northern Hemisphere, whereas the dipole pattern is compensated by reduced cloudiness in the Southern Hemisphere. Apart from this, only the polar latitudes show some larger (but not statistically significant) changes in cloud coverage. Consequently, the impact of the cloud lifetime effect is expected to be small.

- Liquid/ice water content: the patterns for cloud water and cloud ice are characterised by local dipole changes, but there are no significant modifications of the distributions of cloud water and ice. Only the tropical middle to upper troposphere of the Northern Hemisphere shows an enhanced ice mixing ratio in the simulation with lightning emissions, which correlates with the increase in cloud coverage. However, the decrease in cloud coverage in the corresponding region of the Southern Hemisphere is not accompanied by a substantial decrease in ice water. In the zonal average the increase in total water is less than $10 \%$.

- Cloud droplet/ice crystal numbers: compared to the other two parameters, some substantial changes in cloud droplet, and especially in ice crystal number, are found as a consequence of the $\mathrm{LNO}_{x}$ emissions. For the present-day scenario, in the troposphere between 650 and $400 \mathrm{hPa}$, an increase in cloud droplets is simulated in case of active lightning emissions in the tropics. Further north a decrease of cloud droplets between 900 and $600 \mathrm{hPa}$ is calculated. Both are of approximately the same magnitude in absolute and relative terms and are a consequence of more hydrophilic particles due to nitrate coating and a reduction of lower-tropospheric $\mathrm{CCN}$ due to a reduction in lifetime and faster conversion from hydrophobic to hydrophilic conditions. However, the statistical significance of the changes is relatively low. For the ice crystal number the influence is even stronger: in the tropical upper troposphere the $\mathrm{LNO}_{x}$ emissions lead to an increase in the ice crystal number in a region where the highest ice crystal numbers are simulated. In the midlatitudes a reduction of the ice crystal numbers is simulated in both hemispheres above $400 \mathrm{hPa}$. Both modifications are of the order of more than $\pm 20 \%$. Due to the coarse temporal resolution of the model output, it is not possible to attribute the differences to a change in regime from homogeneous to heterogeneous freezing. Nevertheless, it is possible that this effect can occur locally and has a substantial influence on the ice crystal number concentration. 
By analysing the effective radii (Fig. 6), some of the effects on water mixing ratios and numbers are compensated for, whereas others positively amplify each other. This is valid both for liquid clouds in the lower and middle troposphere as well as ice clouds in the middle and upper troposphere. For liquid clouds, the effective radii increase in the simulation with lightning polewards of $40^{\circ}$ below $800 \mathrm{hPa}$ and in the tropics $\left(0\right.$ to $\left.20^{\circ} \mathrm{N}\right)$ up to $400 \mathrm{hPa}$. However, most of the changes are not statistically significant, such that Fig. 6 depicts only the changes in ice crystal size; a corresponding figure for the liquid clouds can be found in the Supplement. The back panel depicts the statistically significant zonal mean change in effective ice crystal size (in absolute units of $\mu \mathrm{m}$ ) in colours. The white contours represent absolute ice crystal sizes with maximum values in the upper part of the midlatitude storm tracks and the upper tropical troposphere. Note that the absolute values (not marked) are of secondary importance as mean values over cloudy and noncloudy conditions are taken, but the difference is robust. For ice clouds the effective radii also increase in the same tropical latitude range between 600 and $200 \mathrm{hPa}$. Additionally, a decrease in effective radii of similar magnitude on the other side of the ITCZ is simulated. Also in the high latitudes, the effective ice crystal size mostly increases in the simulation with $\mathrm{LNO}_{x}$ emissions, both in the upper troposphere as well as in the boundary layer. The shape of the regions of ice crystal changes extends vertically over more than $100 \mathrm{hPa}$ and is not only located in the uppermost troposphere. This indicates that the statistically significant changes are more associated with the process of immersion freezing in mixed-phase clouds than with the cirrus regime with competition between homogeneous and heterogeneous freezing.

Using the KK model configuration, which applies a different cloud droplet activation scheme, results in a lower sensitivity of the liquid droplet effective radius at elevated altitude for present-day conditions. However, in the lower troposphere a similar strong signal is simulated, which leads to an increase of effective droplet radius in the tropical Southern Hemisphere and a decrease in the northern counterpart. For ice crystals, mostly a reduction of effective crystal size is simulated, which is a consequence of the liquid droplet freezing. The effects for preindustrial conditions are similar, with even lower sensitivity of the low clouds on the lightning emissions.

In general, the regions with positive and negative effects in the effective droplet and crystal size show ambiguous signals, such that the impact on cloud radiative properties can only be addressed in conjunction with cloud coverage and the calculation of the radiative fluxes.

\subsubsection{Radiative fluxes}

The combined effects of modifications in the aerosol extinction and the cloud optical properties lead to a modification of the shortwave and longwave radiation fluxes. In Fig. 7 the

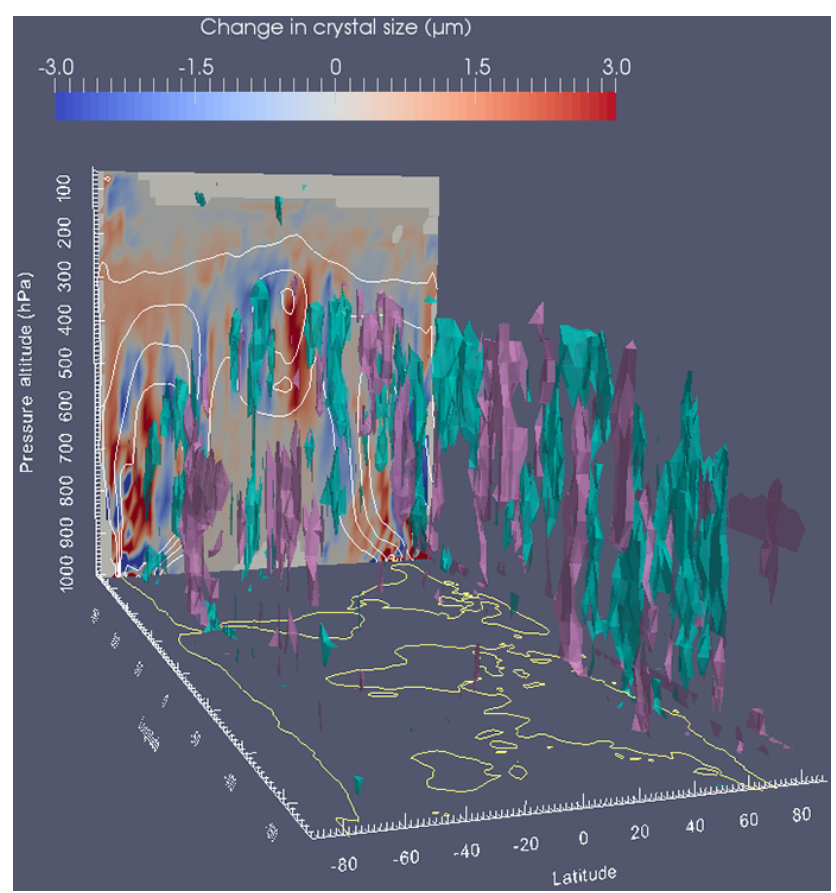

Figure 6. Visualisation of changes in the effective radius of ice crystals. The back panel displays the statistically significant absolute changes in zonal average ice crystal size in $\mu \mathrm{m}$. The white contours depict a mean ice crystal size and therefore mark regions with large and smaller crystals. Additionally, the isosurfaces represent the regions for substantial absolute changes for the effective ice crystal sizes (turquoise for negative and purple for positive) due to the $\mathrm{LNO}_{x}$ emissions.

mean impact on the total sky shortwave flux is depicted in the upper panel. The differences in the SW flux at the top of the atmosphere between a simulation with and one without $\mathrm{LNO}_{x}$ emissions (ARG configuration) are shown. Despite the relatively large internal variability of the system, several regions show a statistically significant change in the TOA shortwave flux (based on a $t$ test with $90 \%$ significance threshold on the annual mean data), which are marked by the hatched regions. However, the regions with increased or decreased fluxes are not directly co-located with the $\mathrm{LNO}_{x}$ emissions. Downwind of central Africa, an increased TOA shortwave flux (corresponding to a heating) is simulated, whereas in northern Amazonia and the maritime continent a decrease of the fluxes (corresponding to a cooling) is calculated. Also, in the midlatitude storm tracks, a slight increase in the fluxes is mostly simulated, whereas over the tropical oceans the model suggests decreased fluxes. In the global mean the overall effect is determined as an enhanced backward reflection of the shortwave radiation of $\sim-0.1 \mathrm{~W} \mathrm{~m}^{-2}$ for all-sky conditions. However, the time series of the global mean differences (depicted in the lower panel of Fig. 7) is characterised by large internal variability with both positive and negative differences. The clear-sky fluxes show a 

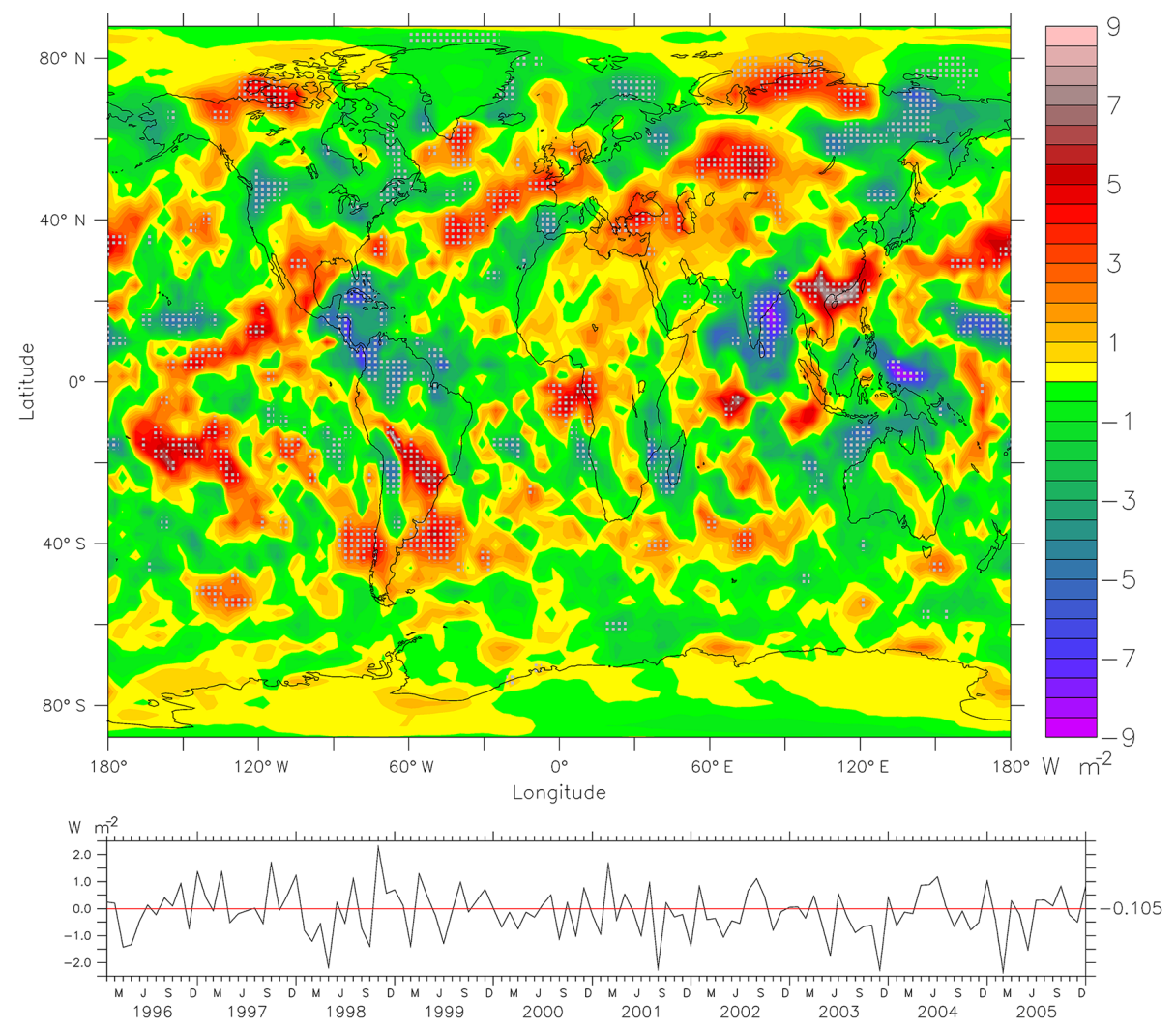

Figure 7. Absolute changes in the shortwave all-sky fluxes at the top of the atmosphere. The upper panel depicts the long-term time average of the difference in the simulation with $\mathrm{LNO}_{x}$ emissions minus the fluxes without lightning emissions. The hatches mark regions with a statistically significant signal (compared to the internal interannual variability). The bottom panel depicts the time series of the monthly mean global mean differences with the red line marking a $0 \mathrm{~W} \mathrm{~m}^{-2}$ change.

substantially weaker signal with only $\sim-0.05 \mathrm{~W} \mathrm{~m}^{-2}$ and hardly any regions with statistical significance. Furthermore, the patterns of substantial changes are clearly separated from the regions where lightning is dominant (i.e. midlatitudes versus tropical continents). Consequently, the clear-sky signal is interpreted as statistical noise.

Considering both the temporal variability of the mean and the large spatial variability, the uncertainty in the total effect has to be considered to be relatively large. Using the sensitivity simulations with the alternative cloud activation scheme reveals a shortwave flux perturbation of $\sim-0.06 \mathrm{~W} \mathrm{~m}^{-2}$ for both present-day and preindustrial conditions, again with no significant contribution from the clear-sky fluxes.

To bring these numbers into context with the total shortwave flux disturbances from anthropogenic aerosols, simulation results with both cloud activation schemes and presentday and preindustrial emission scenarios are compared (for figures see Supplement). Both model configurations show statistically significant cooling over the regions of dominant anthropogenic aerosol pollution (eastern USA, Europe, China) for both clear-sky and all-sky conditions. The clearsky disturbance is $\sim-0.57$ for the ARG and $\sim-0.50 \mathrm{~W} \mathrm{~m}^{-2}$ for the KK configurations. All-sky fluxes change by $\sim-1.62$ for the ARG and $\sim-1.42 \mathrm{~W} \mathrm{~m}^{-2}$ for the KK simulation setups, respectively. The overall anthropogenic aerosol effect is relatively large in the simulations compared to the results published in the latest IPCC report (IPCC, 2013); therefore an overestimated sensitivity to the aerosol disturbance by lightning $\mathrm{NO}_{x}$ nitrate cannot be ruled out completely.

The effect on the longwave radiation via both aerosol extinction and cloud effects is relatively small. In particular, the clear-sky flux disturbances are almost negligible, such that the total effect is dominated by ACI.

Consequently, as the differences between both cloud activation schemes indicate an uncertainty of almost $50 \%$, the quantitative estimate of $-100 \mathrm{~mW} \mathrm{~m}^{-2}$ should also be used with a comparable uncertainty range of $50 \mathrm{~mW} \mathrm{~m}^{-2}$.

\section{Conclusions}

The overall impact of chemically produced aerosol nitrate from lightning $\mathrm{NO}_{x}$ emissions is analysed with a global chemistry climate model. Based on a total emission of $6 \mathrm{Tg} \mathrm{Nyr}^{-1}$, the contribution of $\mathrm{LNO}_{x}$ to the concentrations of upper-tropospheric oxidised nitrogen by more than $57 \%$ for present-day and $75 \%$ for preindustrial conditions. Given 
a sufficient amount of neutralising cations, especially $\mathrm{NH}_{3}$, substantial amounts of aerosol nitrate are formed with the increases in the upper-tropospheric burden exceeding $30 \%$ for present-day and $50 \%$ for preindustrial conditions. Therefore, lightning is also a major contributor to the aerosol nitrate burden in the upper troposphere. The concentration enhancements are not uniformly distributed, but follow the regions of maximum emissions, and are transported further downwind.

Besides the well-known impacts of lightning on $\mathrm{O}_{3}$, the impact on the chemical oxidation capacity of the atmosphere is highly important for the upper-tropospheric aerosol loading. Because of a decrease of the oxidation potential (as represented by an increase in the methane lifetime), the sulfate formation via the gas-phase reaction pathway is reduced in case of neglecting $\mathrm{LNO}_{x}$ emissions. Hence new particle formation is suppressed, efficiently modifying the small part of the aerosol size distribution. In addition to the condensation of nitrate on the aerosol particles, the combination of a reduced particle number and the coagulation of the particles, substantial effects on the particle size distribution in the upper troposphere are simulated.

The changes in aerosol size, chemical composition and number concentrations have implications on climate via both aerosol-radiation and aerosol-cloud interactions. Lightning and its consequences (nitrate formation, size distribution changes) mostly cause an increase in the total aerosol extinction with pronounced increased maxima in the upper troposphere. On the other hand, both liquid and ice-phase cloud optical properties are modified by the $\mathrm{LNO}_{x}$ emissions, represented, e.g. by effective droplet and ice crystal size. However, in contrast to the increases in nitrate concentration, the cloud effects resulting from lightning are ambiguous.
The resulting shortwave flux perturbations caused by $\mathrm{LNO}_{x}$ emissions are quantified to be $\sim-100 \mathrm{~mW} \mathrm{~m}^{-2}$. The resulting effect is caused mostly by the aerosol-cloud interactions, whereas the direct aerosol-radiation interactions are of secondary importance. However, an uncertainty range of almost $\sim 50 \mathrm{~mW} \mathrm{~m}^{-2}$ has to be assumed due to large internal variability and uncertainties in the process description (mostly in the aerosol-cloud interactions).

Nevertheless, an increase in lightning activity in the future or impacts of a more efficient transformation of the $\mathrm{LNO}_{x}$ emissions into nitrate under future climate conditions might have a non-negligible impact on the radiation balance of the atmosphere. On the other hand, aerosol nitrate formed from lightning offers further possibilities to address the feedback and (potentially compensating) impacts of combined chemistry-aerosol-climate interactions.

\section{Data availability}

The simulation data can be made available on request. Please contact the author directly. 


\section{Appendix A: Preindustrial conditions}

The results from the sensitivity simulations for preindustrial conditions are summarised in this section.

- Emissions: in the preindustrial scenario total $\mathrm{LNO}_{x}$ emissions of $6.12 \pm 0.03 \mathrm{Tg} \mathrm{N} \mathrm{yr}^{-1}$ are simulated for the ARG scenario and $6.16 \pm 0.03 \mathrm{Tg} \mathrm{N} \mathrm{yr}^{-1}$ for the $\mathrm{KK}$ simulations.

- Nitrate enhancement: during preindustrial times, an increase in the $\mathrm{HNO}_{3}$ burden with $\sim 67$ and $\sim 76 \%$ in the total and upper troposphere is even stronger compared to present-day conditions. This stronger enhancement is due to the larger contribution of the $\mathrm{LNO}_{x}$ emissions compared to the total $\mathrm{NO}_{x}$ release, which is mostly from anthropogenic sources in present-day conditions. Enhancements for $\mathrm{N}_{2} \mathrm{O}_{5}$ are of $\sim 80 \%$, but also under these conditions $\mathrm{N}_{2} \mathrm{O}_{5}$ is a minor contributor to the total highly oxidised nitrogen tropospheric load (less than $5 \%$ ). A similar figure to Fig. 3 for preindustrial conditions can be found in the Supplement. Due to the lower other sources of $\mathrm{NO}_{x}$ in the atmosphere, the importance of the $\mathrm{LNO}_{X}$ emissions is substantially increased. Therefore, the relative differences in $\mathrm{NO}_{3}^{-}$are larger, which can be seen from the extended areas included by the respective isosurfaces and the larger areas covered by the turquoise contour lines at the floor panel of the figure. The lower overall nitrate mixing ratios are obvious from the colour scale of the column nitrate, which is almost an order of magnitude lower compared to present-day conditions. A lower contribution of particulate nitrate to the total $\mathrm{N}(\mathrm{V})$ load with $22 \%$ for the whole and $9 \%$ for the upper troposphere is simulated, which can be mostly attributed to lower $\mathrm{NH}_{3}$ emissions and consequently less $\mathrm{NH}_{4}^{+}$ions to neutralise and thermodynamically stabilise available aerosol nitrate. However, the enhancement of the particulate phase due to $\mathrm{LNO}_{x}$ is even stronger compared to present-day conditions to $\sim 34 \%$ for the whole troposphere and $17 \%$ for the UT.

- Methane lifetime and sulfate: the lifetime increase is even stronger without anthropogenic emissions, such that for the upper troposphere almost a doubling of the $\mathrm{CH}_{4}$ lifetime occurs (see lower part of Table 2). Nevertheless, this results in a similar reduction of the sulfate burden compared to the present-day without $\mathrm{LNO}_{x}$ emissions, despite the substantially lower total $\mathrm{SO}_{2}$ emissions.
- Size distributions: for preindustrial conditions (see Supplement) the simulation provides similar results to the tropics. However, in the midlatitudes where a substantial reduction of other $\mathrm{NO}_{x}$ emissions is applied compared to the present-day scenario the impact of lightning on the nitrogen budget as well as the size distribution becomes more important. Obviously, a similar pattern as for the tropical continents is simulated; however, due to the weaker $\mathrm{LNO}_{x}$ emissions in the midlatitudes the effects are substantially smaller compared to the tropics.

- Growth factors: the results for the GF are similar in their distribution compared to the present-day scenario with a slightly increased amplitude (up to $\pm 5 \%$ ). The sensitivity simulations KK are characterised by the same distribution and dependencies on the emissions by lightning. Corresponding figures can be found in the Supplement.

- Extinction and AOD: for preindustrial conditions the situation is quite comparable (see Supplement), despite the intensive AOD signals in the regions with anthropogenic pollution, especially East Asia. The simulated global mean column AOD at $550 \mathrm{~nm}$ is 0.090 . Consequently, the enhancement of the extinction between 20 and $50^{\circ} \mathrm{N}$ is less strong. The neglect of the lightning emissions results in a reduced column AOD in most regions, resulting in a global mean value of 0.089. A reduction in column AOD occurs only in regions of strong hydrophobic emissions (dust or BC) where the aerosol lifetime is reduced by a coating by nitrates and subsequent faster conversion from hydrophobic to hydrophilic categories. However, also in this case the statistical significance is relatively small. With respect to the zonal mean extinction the changes are slightly larger compared to present-day conditions.

- Cloud response: for preindustrial conditions the response to the $\mathrm{LNO}_{x}$ emissions is comparable, but shows a slightly higher amplitude.

- Radiative fluxes: for preindustrial conditions (for a graph see the Supplement) the situation is comparable with a slightly increased amplitude of $\sim-0.14 \mathrm{~W} \mathrm{~m}^{-2}$ and a similar pattern distribution. The clear-sky signal is almost negligible with $\sim-0.01 \mathrm{~W} \mathrm{~m}^{-2}$ and no statistical significance. 


\section{The Supplement related to this article is available online at doi:10.5194/acp-17-1125-2017-supplement.}

Competing interests. The authors declare that they have no conflict of interest.

Acknowledgements. Parts of this research were conducted using the supercomputer Mogon and advisory services offered by Johannes Gutenberg University Mainz (http://www.hpc.uni-mainz. de), which is a member of the AHRP and the Gauss Alliance e.V. The author gratefully acknowledges the computing time granted on the supercomputer Mogon at Johannes Gutenberg University Mainz (http://www.hpc.uni-mainz.de).

The author wishes to acknowledge use of the PARAVIEW programme by the Sandia National Laboratories. Sandia is a multiprogramme laboratory operated by Sandia Corporation, a Lockheed Martin Company, for the United States Department of Energy's National Nuclear Security Administration under contract DE-AC0494AL85000.

The author wishes to acknowledge use of the Ferret programme for analysis and graphics in this paper. Ferret is a product of NOAA's Pacific Marine Environmental Laboratory; further information is available at http://ferret.pmel.noaa.gov/Ferret/.

Furthermore, the author thanks all MESSy developers and users for support; further information can be found at http://www. messy-interface.org.

The author thanks the two anonymous reviewers for their constructive comments, which helped to improve this manuscript.

Edited by: K. Tsigaridis

Reviewed by: two anonymous referees

\section{References}

Abdul-Razzak, H. and Ghan, S.: A parameterization of aerosol activation: 2. Multiple aerosol types, J. Geophys. Res.-Atmos., 105, 6837-6844, 2000.

Adams, P. J., Seinfeld, J. H., Koch, D., Mickley, L., and Jacob, D.: General circulation model assessment of direct radiative forcing by the sulfate-nitrate-ammonium-water inorganic aerosol system, J. Geophys. Res.-Atmos., 106, 1097-1111, 2001.

Albrecht, B. A.: Aerosols, Cloud Microphysics, and Fractional Cloudiness, Science, 245, 1227-1230, 1989.

Allen, D. J., Pickering, K. E., Pinder, R. W., Henderson, B. H., Appel, K. W., and Prados, A.: Impact of lightning-NO on eastern United States photochemistry d uring the summer of 2006 as determined using the CMAQ model, Atmos. Chem. Phys., 12, 1737-1758, doi:10.5194/acp-12-1737-2012, 2012.

Banerjee, A., Archibald, A. T., Maycock, A. C., Telford, P., Abraham, N. L., Yang, X., Braesicke, P., and Pyle, J. A.: Lightning $\mathrm{NO}_{x}$, a key chemistry-climate interaction: impacts of future climate change and consequences for tropospheric oxidising capacity, Atmos. Chem. Phys., 14, 9871-9881, doi:10.5194/acp-149871-2014, 2014.
Barth, M. C., Cantrell, C. A., Brune, W. H., Rutledge, S. A., Crawford, J. H., Huntrieser, H., Carey, L. D., MacGorman, D., Weisman, M., Pickering, K. E., Bruning, E., Anderson, B., Apel, E., Biggerstaff, M., Campos, T., Campuzano-Jost, P., Cohen, R., Crounse, J., Day, D. A., Diskin, G., Flocke, F., Fried, A., Garland, C., Heikes, B., Honomichl, S., Hornbrook, R., Huey, L. G., Jimenez, J. L., Lang, T., Lichtenstern, M., Mikoviny, T., Nault, B., O’Sullivan, D., Pan, L. L., Peischl, J., Pollack, I., Richter, D., Riemer, D., Ryerson, T., Schlager, H., Clair, J. S., Walega, J., Weibring, P., Weinheimer, A., Wennberg, P., Wisthaler, A., Wooldridge, P. J., and Ziegler, C.: The Deep Convective Clouds and Chemistry (DC3) Field Campaign, B. Am. Meteorol. Soc., 96, 1281-1309, doi:10.1175/BAMS-D-13-00290.1, 2015.

Bauer, S. E., Koch, D., Unger, N., Metzger, S. M., Shindell, D. T., and Streets, D. G.: Nitrate aerosols today and in 2030: a global simulation including aerosols and tropospheric ozone, Atmos. Chem. Phys., 7, 5043-5059, doi:10.5194/acp-7-5043-2007, 2007.

Bellouin, N., Rae, J., Jones, A., Johnson, C., Haywood, J., and Boucher, O.: Aerosol forcing in the Climate Model Intercomparison Project (CMIP5) simulations by HadGEM2-ES and the role of ammonium nitrate, J. Geophys. Res.-Atmos., 116, D20206, doi:10.1029/2011JD016074, 2011.

Chang, D. Y., Tost, H., Steil, B., and Lelieveld, J.: Aerosolcloud interactions studied with the chemistry-climate model EMAC, Atmos. Chem. Phys. Discuss., 14, 21975-22043, doi:10.5194/acpd-14-21975-2014, 2014.

Christian, H. J., Blakeslee, R. J., Boccippio, D. J., Boeck, W. L., Buechler, D. E., Driscoll, K. T., Goodman, S. J., Hall, J. M., Koshak, W. J., Mach, D. M., and Stewart, M. F.: Global frequency and distribution of lightning as observed from space by the Optical Transient Detector, J. Geophys. Res., 108, 4005, doi:10.1029/2002JD002347, 2003.

de Meij, A., Pozzer, A., Pringle, K. J., Tost, H., and Lelieveld, J.: EMAC model evaluation and analysis of atmospheric aerosol properties and distribution with a focus on the Mediterranean region, Atmos. Res., 114-115, 38-69, doi:10.1016/j.atmosres.2012.05.014, 2012.

Dentener, F., Kinne, S., Bond, T., Boucher, O., Cofala, J., Generoso, S., Ginoux, P., Gong, S., Hoelzemann, J. J., Ito, A., Marelli, L., Penner, J. E., Putaud, J.-P., Textor, C., Schulz, M., van der Werf, G. R., and Wilson, J.: Emissions of primary aerosol and precursor gases in the years 2000 and 1750 prescribed data-sets for AeroCom, Atmos. Chem. Phys., 6, 4321-4344, doi:10.5194/acp-64321-2006, 2006.

Dietmüller, S., Jöckel, P., Tost, H., Kunze, M., Gellhorn, C., Brinkop, S., Frömming, C., Ponater, M., Steil, B., Lauer, A., and Hendricks, J.: A new radiation infrastructure for the Modular Earth Submodel System (MESSy, based on version 2.51), Geosci. Model Dev., 9, 2209-2222, doi:10.5194/gmd-9-22092016, 2016.

Finney, D. L., Doherty, R. M., Wild, O., and Abraham, N. L.: The impact of lightning on tropospheric ozone chemistry using a new global lightning parametrisation, Atmos. Chem. Phys., 16, 75077522, doi:10.5194/acp-16-7507-2016, 2016 .

Finney, D. L., Doherty, R. M., Wild, O., Young, P. J., and Butler, A.: Response of lightning $\mathrm{NO}_{x}$ emissions and ozone production to climate change: Insights from the Atmospheric Chemistry and 
Climate Model Intercomparison Project, Geophys. Res. Lett., 43, 5492-5500, doi:10.1002/2016GL068825, 2016b.

Fountoukis, C. and Nenes, A.: ISORROPIA II: a computationally efficient thermodynamic equilibrium model for $\mathrm{K}^{+}, \mathrm{Ca}^{2+}$, $\mathrm{Mg}^{2+}, \mathrm{NH}_{4}^{+}, \mathrm{Na}^{+}, \mathrm{SO}_{4}{ }^{2-}, \mathrm{NO}_{3}{ }^{-}, \mathrm{Cl}^{-}, \mathrm{H}_{2} \mathrm{O}$ aerosols, Atmos. Chem. Phys., 7, 4639-4659, doi:10.5194/acp-7-4639-2007, 2007.

Gressent, A., Sauvage, B., Cariolle, D., Evans, M., Leriche, M., Mari, C., and Thouret, V.: Modeling lightning- $\mathrm{NO}_{x}$ chemistry on a sub-grid scale in a global chemical transport model, Atmos. Chem. Phys., 16, 5867-5889, doi:10.5194/acp-16-58672016, 2016.

Grewe, V.: Impact of climate variability on tropospheric ozone, Sci. Total Environ., 374, 167-181, doi:10.1016/j.scitotenv.2007.01.032, 2007.

Höpfner, M., Volkamer, R., Grabowski, U., Grutter, M., Orphal, J., Stiller, G., von Clarmann, T., and Wetzel, G.: First detection of ammonia $\left(\mathrm{NH}_{3}\right)$ in the Asian summer monsoon upper troposphere, Atmos. Chem. Phys., 16, 14357-14369, doi:10.5194/acp-16-14357-2016, 2016.

Huntrieser, H., Schlager, H., Roiger, A., Lichtenstern, M., Schumann, U., Kurz, C., Brunner, D., Schwierz, C., Richter, A., and Stohl, A.: Lightning-produced $\mathrm{NO}_{x}$ over Brazil during TROCCINOX: airborne measurements in tropical and subtropical thunderstorms and the importance of mesoscale convective systems, Atmos. Chem. Phys., 7, 2987-3013, doi:10.5194/acp-7-29872007, 2007.

IPCC: Climate Change 2013: The Physical Science Basis, in: Contribution of Working Group I to the Fifth Assessment Report of the Intergovernmental Panel on Climate Change, Cambridge University Press, Cambridge, UK and New York, NY, USA, doi:10.1017/CBO9781107415324, 2013.

Jacobson, M. Z.: Global direct radiative forcing due to multicomponent anthropogenic and natural aerosols, J. Geophys. Res.Atmos., 106, 1551-1568, 2001.

Jaegle, L., Steinberger, L., Martin, R. V., and Chance, K.: Global partitioning of $\mathrm{NO}_{x}$ sources using satellite observations: Relative roles of fossil fuel combustion, biomass burning and soil emissions, Faraday Discuss., 130, 407-423, 2005.

Jöckel, P., Sander, R., Kerkweg, A., Tost, H., and Lelieveld, J.: Technical Note: The Modular Earth Submodel System (MESSy) - a new approach towards Earth System Modeling, Atmos. Chem. Phys., 5, 433-444, doi:10.5194/acp-5-433-2005, 2005.

Jöckel, P., Kerkweg, A., Pozzer, A., Sander, R., Tost, H., Riede, H., Baumgaertner, A., Gromov, S., and Kern, B.: Development cycle 2 of the Modular Earth Submodel System (MESSy2), Geosci. Model Dev., 3, 717-752, doi:10.5194/gmd-3-717-2010, 2010.

Jöckel, P., Tost, H., Pozzer, A., Kunze, M., Kirner, O., Brenninkmeijer, C. A. M., Brinkop, S., Cai, D. S., Dyroff, C., Eckstein, J., Frank, F., Garny, H., Gottschaldt, K.-D., Graf, P., Grewe, V., Kerkweg, A., Kern, B., Matthes, S., Mertens, M., Meul, S., Neumaier, M., Nützel, M., Oberländer-Hayn, S., Ruhnke, R., Runde, T., Sander, R., Scharffe, D., and Zahn, A.: Earth System Chemistry integrated Modelling (ESCiMo) with the Modular Earth Submodel System (MESSy) version 2.51, Geosci. Model Dev., 9, 1153-1200, doi:10.5194/gmd-9-1153-2016, 2016.

Kärcher, B., Hendricks, J., and Lohmann, U.: Physically based parameterization of cirrus cloud formation for use in global atmospheric models, J. Geophys. Res., 111, D01206, doi:10.1029/2005JD006219, 2006.

Kerkweg, A., Buchholz, J., Ganzeveld, L., Pozzer, A., Tost, H., and Jöckel, P.: Technical Note: An implementation of the dry removal processes DRY DEPosition and SEDImentation in the Modular Earth Submodel System (MESSy), Atmos. Chem. Phys., 6, 4617-4632, doi:10.5194/acp-6-4617-2006, 2006a.

Kerkweg, A., Sander, R., Tost, H., and Jöckel, P.: Technical note: Implementation of prescribed (OFFLEM), calculated (ONLEM), and pseudo-emissions (TNUDGE) of chemical species in the Modular Earth Submodel System (MESSy), Atmos. Chem. Phys., 6, 3603-3609, doi:10.5194/acp-6-3603-2006, 2006 b.

Labrador, L. J., v. Kuhlmann, R., and Lawrence, M. G.: Strong sensitivity of the global mean $\mathrm{OH}$ concentration and the tropospheric oxidizing efficiency to the source of $\mathrm{NO}_{x}$ from lightning, Geophys. Res. Lett., 31, L06102, doi:10.1029/2003GL019229, 2004

Labrador, L. J., von Kuhlmann, R., and Lawrence, M. G.: The effects of lightning-produced $\mathrm{NO}_{x}$ and its vertical distribution on atmospheric chemistry: sensitivity simulations with MATCHMPIC, Atmos. Chem. Phys., 5, 1815-1834, doi:10.5194/acp-51815-2005, 2005.

Lamarque, J. F., Bond, T. C., Eyring, V., Granier, C., Heil, A., Klimont, Z., Lee, D., Liousse, C., Mieville, A., Owen, B., Schultz, M. G., Shindell, D., Smith, S. J., Stehfest, E., Van Aardenne, J., Cooper, O. R., Kainuma, M., Mahowald, N., McConnell, J. R., Naik, V., Riahi, K., and van Vuuren, D. P.: Historical (1850-2000) gridded anthropogenic and biomass burning emissions of reactive gases and aerosols: methodology and application, Atmos. Chem. Phys., 10, 7017-7039, doi:10.5194/acp10-7017-2010, 2010.

Lamarque, J.-F., Shindell, D. T., Josse, B., Young, P. J., Cionni, I., Eyring, V., Bergmann, D., Cameron-Smith, P., Collins, W. J., Doherty, R., Dalsoren, S., Faluvegi, G., Folberth, G., Ghan, S. J., Horowitz, L. W., Lee, Y. H., MacKenzie, I. A., Nagashima, T., Naik, V., Plummer, D., Righi, M., Rumbold, S. T., Schulz, M., Skeie, R. B., Stevenson, D. S., Strode, S., Sudo, K., Szopa, S., Voulgarakis, A., and Zeng, G.: The Atmospheric Chemistry and Climate Model Intercomparison Project (ACCMIP): overview and description of models, simulations and climate diagnostics, Geosci. Model Dev., 6, 179-206, doi:10.5194/gmd-6-179-2013, 2013.

Lohmann, U. and Hoose, C.: Sensitivity studies of different aerosol indirect effects in mixed-phase clouds, Atmos. Chem. Phys., 9, 8917-8934, doi:10.5194/acp-9-8917-2009, 2009.

Lohmann, U., Rotstayn, L., Storelvmo, T., Jones, A., Menon, S., Quaas, J., Ekman, A. M. L., Koch, D., and Ruedy, R.: Total aerosol effect: radiative forcing or radiative flux perturbation?, Atmos. Chem. Phys., 10, 3235-3246, doi:10.5194/acp-10-32352010, 2010.

Makkonen, R., Romakkaniemi, S., Kokkola, H., Stier, P., Räisänen, P., Rast, S., Feichter, J., Kulmala, M., and Laaksonen, A.: Brightening of the global cloud field by nitric acid and the associated radiative forcing, Atmos. Chem. Phys., 12, 7625-7633, doi:10.5194/acp-12-7625-2012, 2012.

Mao, K., Ma, Y., Xia, L., Chen, W. Y., Shen, X., He, T., and Xu, T.: Global aerosol change in the last decade: An analysis based on \{MODIS\} data, Atmos. Environ., 94, 680-686, 2014.

Martin, R. V., Jacob, D. J., Logan, J. A., Bey, I., Yantosca, R. M., Staudt, A. C., Li, Q., Fiore, A. M., Duncan, B. N., Liu, H., Gi- 
noux, P., and Thouret, V.: Interpretation of TOMS observations of tropical tropospheric ozone with a global model and in situ observations, J. Geophys. Res.-Atmos., 107, ACH 4-1-ACH 4-27, doi:10.1029/2001JD001480, 2002.

Mayer, B. and Kylling, A.: Technical note: The libRadtran software package for radiative transfer calculations - description and examples of use, Atmos. Chem. Phys., 5, 1855-1877, doi:10.5194/acp-5-1855-2005, 2005.

Ott, L. E., Pickering, K. E., Stenchikov, G. L., Allen, D. J., DeCaria, A. J., Ridley, B., Lin, R.-F., Lang, S., and Tao, W.$\mathrm{K}$ : Production of lightning $\mathrm{NO}_{x}$ and its vertical distribution calculated from three-dimensional cloud-scale chemical transport model simulations, J. Geophys. Res.-Atmos., 115, D04301, doi:10.1029/2009JD011880, 2010.

Petters, M. D. and Kreidenweis, S. M.: A single parameter representation of hygroscopic growth and cloud condensation nucleus activity, Atmos. Chem. Phys., 7, 1961-1971, doi:10.5194/acp-71961-2007, 2007.

Pickering, K. E., Wang, Y., Tao, W.-K., Price, C., and Müller, J.F.: Vertical distribution of lightning $\mathrm{NO}_{x}$ for use in regional and chemical transport models, J. Geophys. Res., 103, 31203-31216, 1998.

Pozzer, A., de Meij, A., Pringle, K. J., Tost, H., Doering, U. M., van Aardenne, J., and Lelieveld, J.: Distributions and regional budgets of aerosols and their precursors simulated with the EMAC chemistry-climate model, Atmos. Chem. Phys., 12, 961-987, doi:10.5194/acp-12-961-2012, 2012.

Price, C. and Rind, D.: A simple Lightning Parametrization for Calculating Global Lightning Distributions, J. Geophys. Res., 97, 9919-9933, 1992.

Pringle, K. J., Tost, H., Metzger, S., Steil, B., Giannadaki, D., Nenes, A., Fountoukis, C., Stier, P., Vignati, E., and Lelieveld, J.: Description and evaluation of GMXe: a new aerosol submodel for global simulations (v1), Geosci. Model Dev., 3, 391-412, doi:10.5194/gmd-3-391-2010, 2010.

Roeckner, E., Bäuml, G., Bonaventura, L., Brokopf, R., Esch, M., Giorgetta, M., Hagemann, S., Kirchner, I., Kornblue, L., Manzini, E., Rhodin, A., Schleese, U., Schulzweida, U., and Tompkins, A.: The atmospheric general circulation model ECHAM5: Part 1, Tech. Rep. 349, Max-Planck-Institut für Meteorologie, available at: http://mms.dkrz.de/pdf/klimadaten/ service_support/documents/mpi_report_349.pdf (last access: January 2017), 2003.

Roeckner, E., Brokopf, R., Esch, M., Giogetta, M., Hagemann, S., Kornblueh, L., Manzini, E., Schleese, U., and Schulzweida, U.: Sensitivity of simulated climate to horizontal and vertical resolution in the ECHAM5 atmosphere model, J. Climate, 19, 37713791, 2006.

Sander, R., Baumgaertner, A., Gromov, S., Harder, H., Jöckel, P., Kerkweg, A., Kubistin, D., Regelin, E., Riede, H., Sandu, A., Taraborrelli, D., Tost, H., and Xie, Z.-Q.: The atmospheric chemistry box model CAABA/MECCA-3.0, Geosci. Model Dev., 4, 373-380, doi:10.5194/gmd-4-373-2011, 2011.

Schumann, U. and Huntrieser, H.: The global lightning-induced nitrogen oxides source, Atmos. Chem. Phys., 7, 3823-3907, doi:10.5194/acp-7-3823-2007, 2007.
Steinkamp, J. and Lawrence, M. G.: Improvement and evaluation of simulated global biogenic soil NO emissions in an AC-GCM, Atmos. Chem. Phys., 11, 6063-6082, doi:10.5194/acp-11-60632011, 2011.

Stelson, A., Friedlander, S., and Seinfeld, J.: A note on the equilibrium relationship between ammonia and nitric acid and particulate ammonium nitrate, Atmos. Environ., 13, 369-371, 1979.

Tanre, D., Geleyn, J.-F., and Slingo, J. M.: Aerosols and Their Climatic Effects, in: chap. First results of the introduction of an advanced aerosol-radiation interaction in the ecmwf low resolution global model, A. Deepak, Hampton, VA, 1984.

Tiedtke, M.: A Comprehensive Mass Flux Scheme for Cumulus Parametrization in Large-Scale Models, Mon. Weather Rev., 117, 1779-1800, 1989.

Tost, H. and Pringle, K. J.: Improvements of organic aerosol representations and their effects in large-scale atmospheric models, Atmos. Chem. Phys., 12, 8687-8709, doi:10.5194/acp-12-86872012, 2012.

Tost, H., Jöckel, P., Kerkweg, A., Sander, R., and Lelieveld, J.: Technical note: A new comprehensive SCAVenging submodel for global atmospheric chemistry modelling, Atmos. Chem. Phys., 6, 565-574, doi:10.5194/acp-6-565-2006, 2006.

Tost, H., Jöckel, P., and Lelieveld, J.: Lightning and convection parameterisations - uncertainties in global modelling, Atmos. Chem. Phys., 7, 4553-4568, doi:10.5194/acp-7-4553-2007, 2007.

Tost, H., Lawrence, M. G., Brühl, C., Jöckel, P., GABRIEL-Team, and SCOUT-O3-DARWIN/ACTIVE-Team: Uncertainties in atmospheric chemistry modelling due to convection parameterisations and subsequent scavenging, Atmos. Chem. Phys., 10, 1931-1951, doi:10.5194/acp-10-1931-2010, 2010.

Twomey, S.: The Influence of Pollution on the Shortwave Albedo of Clouds, J. Atmos. Sci., 34, 1149-1152, doi:10.1175/15200469(1977)034<1149:TIOPOT>2.0.CO;2, 1977.

van der Werf, G. R., Randerson, J. T., Giglio, L., Collatz, G. J., Mu, M., Kasibhatla, P. S., Morton, D. C., DeFries, R. S., Jin, Y., and van Leeuwen, T. T.: Global fire emissions and the contribution of deforestation, savanna, forest, agricultural, and peat fires (19972009), Atmos. Chem. Phys., 10, 11707-11735, doi:10.5194/acp10-11707-2010, 2010.

$\mathrm{Xu}, \mathrm{L}$. and Penner, J. E.: Global simulations of nitrate and ammonium aerosols and their radiative effects, Atmos. Chem. Phys., 12, 9479-9504, doi:10.5194/acp-12-9479-2012, 2012.

Yang, Q., Easter, R. C., Campuzano-Jost, P., Jimenez, J. L., Fast, J. D., Ghan, S. J., Wang, H., Berg, L. K., Barth, M. C., Liu, Y., Shrivastava, M. B., Singh, B., Morrison, H., Fan, J., Ziegler, C. L., Bela, M., Apel, E., Diskin, G. S., Mikoviny, T., and Wisthaler, A.: Aerosol transport and wet scavenging in deep convective clouds: A case study and model evaluation using a multiple passive tracer analysis approach, J. Geophys. Res.-Atmos., 120, 8448-8468, doi:10.1002/2015JD023647, 2015.

Zare, A., Christensen, J. H., Gross, A., Irannejad, P., Glasius, M., and Brandt, J.: Quantifying the contributions of natural emissions to ozone and total fine PM concentrations in the Northern Hemisphere, Atmos. Chem. Phys., 14, 2735-2756, doi:10.5194/acp14-2735-2014, 2014. 